\title{
Tone Systems, angklung, keromong, Dancing and Gender Aspects
}

As already mentioned, the earliest written sources about Baduy music, other than the Old Sundanese manuscripts, date from the beginning of the 19th century. The information in these reports cannot always be taken at face-value. The angklung (now a set of 9 bamboo idiophones, which are shaken) is mentioned by almost all 19th century visitors to the area: Blume (1993[1822]: 32), Spanoghe (1838: 303), Van Hoëvell (1845: 429), Koorders (Meinsma 1869: 331), Jacobs and Meijer (1891: 24). However, it is not always clear whether the remarks concern the Inner or the Outer Baduy, or even the surrounding Sundanese. For instance, Jacobs and Meijer (1891: 24) report that the Baduy only have angklung and kacapi and that they are not allowed to have other instruments. I presume that these authors refer to the Inner Baduy, but even then this seems to be wrong. Inner Baduy have always had the karinding Jew's harp, and the tarawélét (or taléot) and kumbang flutes as well, as far as we know.

Jacobs and Meijer (1891: 24) also mention that the Baduy angklung consists of four instruments and that is very different from the nine instruments that are used nowadays in every ensemble in Kanékés. Without further evidence it seems likely that Jacobs and Meijer made a mistake. These authors classified the pantun stories under 'language and literature' and discussed it in a special section of their book, written by Meijer (Jacobs and Meijer 1891: 111-175). That the Baduy recite pantun stories that are known in the whole of West Java was also mentioned by several other 19th century authors as will be further explained in Chapter 6 that is based on Van Zanten 2016a (see also Van Zanten 1989: 18-21; 1993: 144-148). In his article Van Hoëvell (1845: 411-427) discusses the sung four-line poems, called susualan or sisindiran in Sunda (and pantun outside Sunda - see Van Zanten 1989: 68-70). Van Hoëvell presents several verses in Sundanese and Dutch translation. Chapter 7 will discuss some Baduy susualan that I recorded.

None of these 19th century authors mention a keromong (gamelan) in the Outer Baduy area, and it may be that this is a relatively recent addition to the Outer Baduy instruments. However, the word goong, currently used for gong and also another word for Sundanese gamelan, is frequently mentioned in the pantun stories and it may stand for the king and/or the kingdom. In Section 6.5 , Table 13, I mention a Baduy pantun text about a gamelan/goong that is out 
of tune and at risk of being stolen. Hence the Baduy may at least have known about the existence of gamelan ensembles for several centuries. My information was that the Baduy smiths never made the bronze gamelan instruments themselves and that these were bought outside Kanékés. This was confirmed by Garna (1988: 214), who mentions that the Baduy do not make their own gamelan instruments, but do make most other instruments, like angklung, bedug (drums), karinding, suling, rendo and kacapi themselves.

Below I will argue that both the angklung and keromong are using the saléndro tone system of five notes in each octave with the same interval between consecutive notes. Therefore Section 5.1 will discuss this saléndro tone system and the other system known to the Baduy, but not really used, it seems: the pélog tone system. However, the information is not yet very sound and it may be that playing styles, more related to social factors, are more relevant than tuning systems. Baduy travel, visit market places, listen to the radio and watch television, and therefore we may assume that most of them have heard diatonic and other tone systems.

\subsection{General Musical Concepts: Tone Systems, Modes and Styles of Playing}

This section discusses a few general issues concerning music concepts, like the used tone system and styles of playing. Although in Kanékés the Baduy try to control outside influences, they are not isolated, also not in a musical sense. They travel around and hear other musics: from Sunda and from other parts of the world. I am sure that most Baduy musicians know the sound of the diatonic (Western tuning) angklung as played in the Saung Angklung Udjo in Bandung. Baduy buy instruments that were made outside Kanékés, notably the gamelan sets, but also flat zithers and violins. This also means that certain music concepts and terminology were adopted from the present Sundanese music tradition. However, it is difficult to see how the music concepts developed during the last few centuries as we lack sufficient information. Here I will only raise a few issues and in particular the used tone systems. However, before starting to discuss the tone systems, I will say a few things about the transcriptions of music that I will use for analysis.

\subsubsection{Transcription of Music for Analysis}

Chapters $5^{-8}$ will present transcriptions of some recorded music in Western staff notation. These transcriptions will mainly be used for simple musical analysis and I will add some information on the technical production of the 
music, if available. It has already fairly extensively been reported in literature that a representation of sound by a transcription on paper does not give the final answer to the question of what the musicians want us to hear. Moreover, music may be transcribed in many ways and it is not entirely 'objective'; we should be careful for ethnocentric biases. This is certainly also the case for Baduy music: we have limited knowledge about their ideas on how the music should sound.

Generally speaking, my background is Western music, slightly influenced by listening to Malawian music, and greatly influenced by what I learned by listening to Cianjuran music in Bandung. Because our knowledge about what is important in Baduy music is limited, it is difficult to avoid biases in the transcriptions. The central point, like for all scholarly work, is whether we transcribe the relevant, or better - valid - features and not the irrelevant ones; see also the beginning of Chapter 3 . For instance, I used the concepts of 'melody' and 'ornament' for transcribing songs and flute playing in my music transcriptions. We may ask whether it is correct to make this analytical difference for Baduy music.

For the transcriptions I used my ears, the audio computer programme $\mathrm{Au}$ dacity 2.0.6 (2014) and the PRAAT 5.3.63 (2014) programme for speech analysis. The pitch of the notes is always an approximation. Moreover, I used five types of basic note lengths in the staff notation: the whole, half, quarter (quaver), eighth (semiquaver) and sixteenth (demisemiquaver) notes. In addition I mostly used grace notes (small-sized notes in print) when the speed was about a sixteenth note or faster. All the grace notes take time from the note to which they are connected by a slur. This temporal distinction between the notes is only a rough classification. However, with this less strict temporal organisation of the musical notes the notation becomes easier to read and we may avoid claims that the transcription is 'precise' and a standard for performances.

The musicians themselves did not differentiate between grace notes, or musical ornaments and notes of the melody. A more detailed study about this is needed. Here I mainly used my information about Cianjuran music and distinguished the Baduy 'ornaments' consisting of one, two, or more notes, that is, respectively: (1) appoggiatura or note of complement, (2) double appoggiatura, and (3) shakes (pitch vibratos), mordents, turns. Further, flute players used glissando: that is, gliding from a note to another one by relatively slowly opening or closing a finger hole (see Chapter 8). It turns out that in the transcribed music the Baduy flute players only used glissando from a higher to a lower note, in the transcriptions indicated by an (undulating) declining line, and not from a lower to a higher note. 
When preparing this book, I used the computer programme 'Finale 2014' for producing the Music Transcriptions. This is a flexible programme, in which for instance the measure bars can be made invisible for music that is not strictly organized in bars but rather performed in a rubato style, like the pantun singing (Chapter 6) and the flute playing (Chapter 8). However, the Finale programme keeps 'thinking in bars'. This means that in the transcriptions I sometimes slightly adjusted the duration of notes and rests.

Sometimes I use the signs (accidentals) for raising a note by a semitone (sharp), or lowering the note by a semitone (flat) at the beginning of the staff. In this book this has nothing to do with the Western concept of 'key'. For example, two flats at the beginning of the staff on the ' $b$ ' and 'e' lines are just meant to avoid writing flat-signs for each individual note 'b' and 'e'. Similarly, a sharp at the beginning of the staff on the ' $\mathrm{f}$ ' line just means that every ' $f$ ' has to be read as 'f-sharp'. In some cases, the (many) accidentals have been avoided by transposing the music. However, on the whole I tried to avoid transposition, because in other parts of Sunda the absolute tuning is an important characteristic of the type of music (see, for instance Van Zanten 1989: 116-118).

If needed, I will notate the notes in the different octaves from low to high:

\begin{tabular}{|c|c|c|}
\hline Great octave & notes C-D-E-F-G-A-B & $\begin{array}{l}\text { in range } 65-123 \text { Hertz } \\
\text { (vibrations per second); }\end{array}$ \\
\hline Small octave & notes c-d-e-f-g-a-b & in range 131-247 Hertz; \\
\hline One-line octave & notes $c^{1} \ldots . . b^{1}\left(\right.$ or $\left.c^{\prime}-b^{\prime}\right)$ & in range $262-494$ Hertz; \\
\hline Two-line octave & notes $c^{2} \ldots . b^{2}$ (or c"-b") & in range $523-988$ Hertz; \\
\hline Three-line octave & notes $c^{3} \ldots . . b^{3}$ (or c"'-b"') & in range $1047-1976$ Hertz. \\
\hline
\end{tabular}

\subsubsection{Tone Systems}

In the Priangan area, the mountainous area roughly between Bogor and Tasikmalaya and between Sukabumi and Cirebon, the tone systems are often called pélog and saléndro. Simply said, in this region the saléndro tone system is an equidistant pentatonic system: 5 tones in each octave and with the same interval between each pair of consecutive notes (just more than two Western semitones, or 240 cent.) $)^{1}$ The pélog tone system also consists of five major notes

1 One hundred cent is equal to a Western semitone interval (distance) and an octave is equal to a 1200 cent interval. The cent interval is based on the logarithm of a frequency ratio of two tones. 
in each octave, but with different intervals between the consecutive pairs of notes, ranging from about one to four Western semitones or from 100 to 400 cent (Van Zanten 1989: Chapter VI). Baduy musicians also use the terms saléndro and pélog. The tunings of the instruments of three angklung ${ }^{2}$ and three keromong ensembles that I recorded ${ }^{3}$ confirm that these ensembles use the saléndro tone system. Tunings of other instruments (like zithers and flutes) do not always give unambiguous evidence of what the tuning model is meant to be. Those tunings will not be discussed in detail as it is beyond the scope of this book.

For instance, the tuning of the eleven strings of the kacapi played by Sajin to accompany the pantun story Lutung Kasarung in January 1977 considerably deviated from the saléndro model (see Table 16 in Section 6.5). However, the analysis of Sajin's vocal part in the pantun recitation is fairly clear: the singing may be considered to use a saléndro tone model. This may also be seen from Music Transcription Tr 1 below that gives the graphical notation of the pitch and intensity in the first 20 seconds (two times 10 seconds) of Sajin's singing at the start (rajah). This picture was produced with the PRAAT programme for the analysis of speech (PRAAT 2014) that is also very useful for our purposes. The horizontal lines are each a Western semitone, or 100 cent, apart. The lowest (unbroken) line represents the tone A of 110 Hertz; the unbroken line 7 semitones higher represents the Western tone 'e' of 165 Hertz and the unbroken line 12 semitones (one octave) higher than the lowest line (A) represents the Western tone 'a' of 220 Hertz. The highest line, 19 semitones above A, is $\mathrm{e}^{1}$ (330 Hertz). The horizontal axis gives the time in seconds. Below the graph of the pitch is a graph showing the corresponding loudness (intensity) of the tones in decibel $(\mathrm{dB})$.

From Music Transcription $\operatorname{Tr} 1$ it may be seen that Sajin uses the tones that may, from high to low frequencies, approximately be equated with the Western notes b-flat, a-flat, f, e-flat and d-flat, respectively lying 2, 3, 2, 2 [and 3] semitones apart. This is generally considered an approximation of the saléndro tone system. To avoid many accidentals ('flats'), in the Music Transcription $\operatorname{Tr} 5$ (Section 6.5) I have transposed all notes up by one semitone. Sajin's vocal tones are then transcribed in Western staff notation as (from high to low

2 Angklung Gajéboh, recorded 24 September 1976 (tape B7, item 3), Angklung Cipangembar, recorded 16 July 1979 (tape B19, item 4), Angklung Kadujangkung, recorded 24 October 1992 (DAT 92-O3, 1:13:34-1:19:46).

3 Keromong Gajéboh \#1, recorded 12 June 1976 (tape B1, item 3); Keromong Gajéboh \#2 recorded 21 July 1976 (tape B6, item 3); Keromong Kompol, recorded 24 July 1976 (tape B7, item 1). 

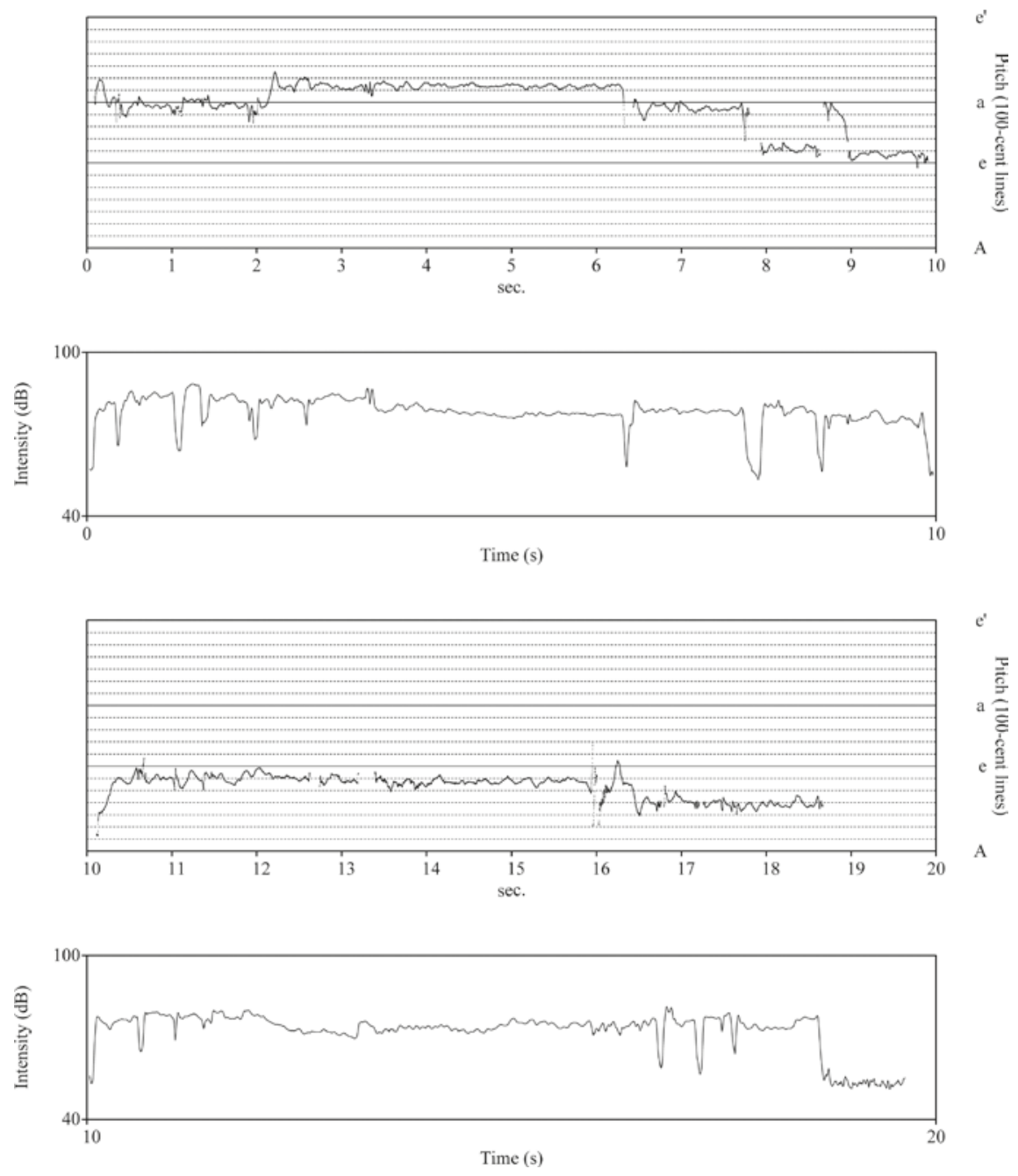

MUSIC TRANSCRIPTION TR 1 Graphical notation of pantun singing by Sajin 1977, produced with the computer programme PRAAT (first 20 of 40 seconds are shown)

frequencies) $\mathrm{b}-\mathrm{a}-\mathrm{f} \#-\mathrm{e}-\mathrm{d}$. Hence $\operatorname{Tr} 5$ in Section 6.5 is about one semitone above the original sound that is represented in Music Transcription $\operatorname{Tr} 1 .{ }^{4}$

4 Note that in Music Transcription Tr 5 in Section 6.5 I opted for writing the accidentals '\#' for the note ' $\mathrm{f}$ ' at the beginning of each staff: all notes ' $\mathrm{f}$ ' are raised by a semitone and should be read as ' $\mathrm{f} \#$ '. See also the last part on transcriptions above. 
More than a century ago, Pleyte also published a music transcription of the start of a rajah by a Baduy bard. The music transcription (Pleyte 1912: after p. 425) used the notes, from high to low frequencies: $\mathrm{c} \#-\mathrm{b}-\mathrm{g} \#-\mathrm{f} \#-\mathrm{e}-$ c\#. Although Pleyte and the anonymous transcriber do not mention the word 'saléndro' or 'equidistant', this is clearly meant to be a transcription of singing in a saléndro tone system. In this transcription the kacapi is also included and regularly plays three short notes, from high to low frequencies: $\mathrm{b}-\mathrm{f} \#-\mathrm{b}$ and some long notes on b. ${ }^{5}$ In 1977 Sajin played similar short patterns on his kacapi. Listening to Sawari in my 2003 recording, it is also fairly clear that in his unaccompanied singing he is using a saléndro tone system. In the transcription of singing with zither and bowed violin by the female vocalist Raidah (Raida) in 1992, I also used the saléndro tone system (Van Zanten 1995: 542-543).

Without further evidence it seems that the Baduy use a saléndro tone system in the pantun recitation. The Baduy say that the keromong and angklung instruments are also tuned according to the saléndro tone system (see for instance Anirah, A2016-1: 65) and my measurements seem to confirm this. With respect to the other instruments, like the flutes and the rendo, the situation is less clear. These instruments are often played solo and there is no standardization. Only when instruments like a flute and a zither are playing together, the tuning of the zither is adjusted to the tuning of the flute. The tuning of the suling kumbang played by Karamaén and recorded in June 2014 (see Table 18, Section 8.1) may be called to be more or less saléndro. For the tarawélét things are more complicated. In the higher octave with the three first and two second overtones we may speak about saléndro, but in the lower octave with the three fundamentals the tarawélét flutes produce only three notes of a possible 'saléndro' system; there is a gap of two saléndro notes between the lowest and the higher octave (see Table 21 in Section 8.2).

I wondered whether some Baduy instruments could be using a type of pélog tone system, as in the Baduy pantun stories the 'goong pélog' (pélog gamelan/ gong) is mentioned: see, for instance Table 13 in Section 6.5. Moreover, some Baduy musicians talked about pélog being used by them. The zither player Satra said that pantun recitation used bangbrang (or pasieup) pélog and singing sisindiran/susualan was in bangbrang saléndro (A2003-1: 50-51). Nevertheless, I am inclined to conclude that currently the Baduy do not have instruments or singing that use a pélog tone system, and that the bangbrang pélog rather means a style of playing or sound quality. I will present some evidence for

5 Five years earlier Pleyte had given a kacapi pantun tuning, arranged from high to low frequencies as: $\mathrm{d}-\mathrm{c}-\mathrm{a}-\mathrm{g}-\mathrm{f}-\mathrm{c} \#[$ ? I am not sure about this last one]. (Pleyte 1907: 26-27, footnote). This could be seen as 'fairly similar' to a saléndro tuning. 
this. In Section 5.4 below (The history of a Baduy gamelan between 1976 and 2019) I mention that the tuning of this gamelan was described as pélog, and that the Baduy did not like that tuning. They wanted their keromong to be tuned like the gamelan that is used to accompany the wayang golék puppet play, that is, in saléndro.

The transcription of Sawari's song in Van Zanten (1995:541) seems to indicate the use of a pélog tone system with some semitone intervals in it. However, there is a story behind this that may be read on p. $53^{1}$ of my 1995 article. I wrote:

Before Sawari came into the house where I was going to record him [in Cipangembar, a resettlement hamlet outside Kanékés], I had tuned the kacapi (on which he was to play) to the pélog tone system, as used in Tembang Sunda Cianjuran, a Sundanese genre not played by the Baduy. I asked him to check the tuning of the instrument before he started. He tried the tuning, did not change anything, and said it was correct. Sawari knew the terms for the two Sundanese tone systems (called pasieup by him) - pélog and saléndro - but he was obviously confused about them. Some of the songs he proceeded to sing were in saléndro, he said, although he was clearly singing in the pélog tone system to which I had tuned his instrument. This suggests that the Baduy, like other Sundanese, can easily play a song in different tone systems (pélog or saléndro). These form different modes of the same song. ${ }^{6}$

It seems that in current practice the Baduy take 'pélog' to mean any tuning that is 'not saléndro' or 'not right', that is, a tuning that is too much deviating to be called saléndro. Saléndro is preferred and pélog is not. Pélog seems also to be used for an unwanted, a false, an inaccurate tuning, it seems. Possibly notes that are played, but outside the used saléndro system (often grace notes), could also be called pélog notes. I assume that most Baduy have heard the diatonic tuning as used in pop music and also the diatonic angklung played in Bandung (see next section), and that they do not really prefer those tunings for their own music. So, what happened when the gamelan degung was introduced and developed, probably at the seat of the regent of Cianjur two hundred years ago, with a tuning described by Kunst as 'at first hearing, this degung-scale seems to

6 Elsewhere I have described the great need to develop a new theory for the Sundanese modal systems that is firmly based on musical evidence, as Kusumadinata's models are not very useful. See also Section 6.5, Cook (1993) and Van Zanten (1989: 131-134; 2014: 216-217, or the Indonesian translation 2016b: 241-243). 
be a kind of europeanized pentatonic pélog ...?' (Kunst 1973: 377 in Van Zanten 1989: 126). We need further research on this.

Unfortunately the available literature is not very clear about the Baduy concepts of music, including the tone systems. In the 1920s Brandts Buys and Brandts Buys-van Zijp (1926: 59-6o) had similar problems in determining whether a Sundanese suling player from Garut used a pélog or a saléndro tone system. The player said that he was playing in pélog, but Brandts Buys and his wife heard a saléndro-like system that they used in their transcription: an 'anhemitonic' (without Western semi-tone intervals) pentatonic system, from low to high: d, e, f\#, a, b, d.

According to Anis Djatisunda, the Baduy and Sundanese originally (in pantun kuno) had two styles of performing (he called them 'laras'): rindu and carang-carang (interview on 18 July 1978 in Sukabumi, Ar977-9: 24). Carangcarang means: with large intervals, wide apart; rindu means: longing, languishing, and desiring (Eringa 1984). Djatisunda's information may have been derived from Suryadi's work (1974: 59), who wrote: 'the Baduy community knows two types of tone system that they call pasieupan carang-carang and pasieupan rindu'. He mentioned that the Baduy used the word pasieupan as meaning 'the term laras [tone system] generally [used by] the Sundanese community' in West Java. Soepandi (1995a: 19) also mentioned these two 'ways of playing', and he connected them to the tone systems in the urban areas: the tone system (pasieupan/tangganada) 'carang-carang/saléndro and the tone system rindu/ pélog/kerep'. He continues for suling lam(b)us: ' 'When he wants a cheerful atmosphere, the flute player uses (menyajikan) carang-carang. If the sound is used to break the heart (menyayat hati) of a girl, a song is used with notes of the rindu/kerep tone system'. Kerep means: close together (Eringa 1984).

I also obtained information that carang-carang and rindu are ways of playing in Baduy angklung music. Carang-carang is used for happy occasions and it 'may be heard from far'. In contrast, the rindu way of playing is soft and intimate. Possibly it would be better to describe carang-carang and rin$d u$ as qualities of the sound (pasieup) produced by an angklung or keromong set. This sound should fit, be harmonious (sieup) to, the social situation in which it is used. According to Ojél, leader (jaro angklung) of the angklung group in Kadujangkung, their angklung set was rindu. A carang-carang angklung set and a rindu angklung set can both play all the songs of the repertoire, but with a different sound quality. Hence possibly this sound quality indicates a different mode of the song. Satra told that the kacapi pantun has

7 Called galéong by Soepandi. 
rindu quality (bangbrang rindu). For susualan singing the bangbrang saléndro is used, whereas for pantun recitation it is the bangbrang pélog (A20031: 50). Satra's statement on pantun recitation is not confirmed by my musical analysis of Sajin's pantun singing: Sajin is using a saléndro tone system. ${ }^{8}$ Ojél also said that keromong sets could be carang-carang, rindu or ombak banyu. ${ }^{9}$ According to him, the Baduy did not use the tone systems pélog and saléndro (A1992-1: 38-39, 14 October 1992). However, I conclude that nowadays the Baduy commonly apply the term saléndro to the tuning of Baduy instruments, in particular angklung and keromong.

The word bangbrang or brangbrang is also used for 'octave' (A1992-1: 38, Ojél; A2003-1: 50, Satra; A2014-1: 40, Kompol). ${ }^{10}$ Karamaén (MD 2003-13) and Satra (A2003-1: 50-51) seem to use b(r)angbrang as a style of playing as well, and possibly in the sense of (musical) mode. Pleyte (1907: 26-27, footnote 1) gives bangbrang and bangbrang anak as the names for two kacapi strings. See also Section 8.4 below.

The word lagu is used to indicate 'melody' or 'song', like in many other parts of Indonesia, and most songs or melodies have a name. In Old Sundanese manuscripts the word lagu meant 'time', 'period', 'the time has come' (tiba saatn$y a$ ), 'duration' (Atja and Danasasmita 1981c: 62). In modern Sundanese it is still used in that way (Eringa 1984: 437, lagu 2; Noorduyn and Teeuw 2006: 375).

I did not collect many more general musical concepts. The coming chapters contain some more terms that are particularly relevant for the type of music described there. For instance, for angklung the introductory section to any piece of music is called burulung (Rasudin, A2013: 27). Moreover, an angklung piece is always concluded with fast and loud playing while the players stand still and the dancers and drummers run around them: ngagubrugkeun (Van Zanten 1995: 533). For ending a musical phrase, a rendo player will pluck the open string of the rendo; the phrase is ended, like a note of a large gong in the gamelan ensemble.

It seems that the (absolute) pitch plays a less important role in Baduy music than different types/styles of playing that fit the social situation. The music

8 On the basis of what I heard by ear, I would say that also all other Baduy storytellers that I heard (Sawari, Anirah, Harépin, and Yaldi) sang in saléndro.

9 I do not have more information about keromong with the ombak banyu characteristics. I recall that the gong-smith Sukarna in Bogor distinguished three types of vibrato in the large gongs: ombak banyu, ombak sekar gadung and ombak puyungkung. Ombak banyu is the slowest and ombak payungkung the fastest; this was wrongly reversed in Van Zanten (1989: 176).

10 In Sundanese music the term beulit (Soepandi 1995b), or gembyang (Van Zanten 1989:113) is used for octave. 
should be 'harmonious' (sieup) with the social circumstances. This seems regularly to be expressed in tempo differences, rather than in pitch differences. More research needs to be done on this issue.

\subsection{Angklung for Rituals and for Entertainment}

Baduy angklung refers to an ensemble of 9 bamboo idiophones with one to three drums; see Figures 34-36. Each idiophone consists of three tubes in a frame that is shaken and each such instrument on its own is also called angklung. The three tubes within the frame are tuned in octaves, resulting in an interval of two octaves between the lowest and the highest tube.

Two centuries ago Raffles (1817: 472, Plate between pp. 168-169) described angklung played in the interior [of Java], and in particular in the Sunda districts. He mentioned that the instrument 'is formed of five or more tubes of bámbu, cut at the end after the manner of the barrels of an organ'. The tubes have 'graduated lengths' of $50-20 \mathrm{~cm}$ and are placed in a frame. The instruments are played by $10-50$ men, each playing one instrument, and accompanied by 'one or two others with a small drum played with the open hand'. The instruments 'are generally decorated with common feathers, and the performers, in their appearance and action, are frequently as grotesque and wild as can be imagined'. The music is performed on 'occasions of festivity'. Generally Raffles' information also applies to the present situation, but some information is puzzling. The picture of an angklung instrument shows indeed the five tubes, but these are more or less of the same length. Moreover, nowhere in the literature after Raffles I have seen a description of angklung instruments with five tubes in one frame. For instance, writing about the whole of Indonesia, Kunst (1973: 361-364) speaks of 'the shake-angklung [that] consists of two or three bamboo segments, usually tuned to as many octaves'. In the 1960s-1970s street musicians in west Java often used angklung instruments with two or three bamboo segments, it seems: see photograph in Hood (1971: 257).

Jacobs and Meijer (1891: 24) mentioned that the Baduy angklung set contains only four instruments. Randal Baier discusses Sundanese angklung sets in several parts of West Java. He mentions that the Sundanese angklung 'is a framed bamboo instrument consisting of from two to four tuned bamboo tubes that produce sound when shaken' and that some ensembles employ 'only two drummers, at times only four angklung, and without auxiliary instruments or performers'. (Baier 1986: 2-1, 2-2). The overview of Sundanese types of angklung in Masunah et al. confirms Baier's remarks, in particular that the angklung instruments have 2-4 tubes in one frame (Masunah et al. 2003: 20). However, 
although the Baduy angklung is described by Masunah et al., no audio-visual example of Baduy angklung is included on the accompanying CD and VCD.

During the period that I did my fieldwork between 1976 and 2016, I only saw Baduy angklung ensembles that consisted of 9 different instruments. The intervals between consecutive notes produced by the different Baduy angklung instruments are approximately equidistant and there are five equidistant intervals within one octave. The indung leutik instrument produces a tone (and its octaves) that is one octave higher than the indung gedé instrument. Thus the tuning of the nine instruments resembles the Sundanese saléndro tone system; see also the discussion in Section 5.1 above. The two highest instruments are called loér or roél and played together by one person; the other seven instruments are each played by one person. Each person has to play his instrument at a particular time and by this 'interlocking' technique a melody is constructed by the sequence of produced notes. Each drum is played by a different person. The drums are kept on the left, in the hand and with a string around the neck and beaten with the right hand; no sticks are used (see film fragment $<\mathrm{AV}_{5}>$ with three drum players and two dancers). The names of the different angklung instruments and drums are given in Table 6, from highest (leutik or alit, 'small') to lowest (gedé, 'large') produced tones. For each instrument the tube in the medium octave is sometimes called child (anak) and the tube in the highest octave grandchild (incu; recording DAT92-13, ca. 1h14m).

In December 2013 Rasudin, leader of the angklung group (jaro angklung) near the house of the secular village head in Kaduketug, explained that there were couples (pasangan) of instruments: 1. \{indung leutik, indung gedé\}, 2. \{éngklok, ringkung\} and 3. \{gunjing, dongdong\}; see also Figure 34. This was confirmed by jaro pamaréntah Saijah and pantun storyteller Anirah in 2016." Each pair of these instruments will play the notes at the same time, and in this order of sets (1-2-3); the fourth set of loér 1, loér 2 and the torolok instruments will follow and play the melodic structure (A2016-1: 65), as will be discussed in more detail below.

Outer Baduy use angklung with two or three drums; if only two drums are used, this seems always to be the one with medium pitch, talinting, and the lowest one bedug. In the Inner Baduy area there are only one or two drums used with the angklung ensemble and the highest drum ketuk is not used. In Cibéo they only use the lowest bedug drum and in Cikeusik and Cikartawana they use both the lowest and the medium drums: bedug and talinting.

11 Anirah also makes sets of angklung instruments, rendo, and kacapi. He said that in 2016 a whole angklung set, including drums, would cost about two million Rupiah, that is, about $€$ 138, Us\$152 (A2016-1: 65); see also Table 4. 
TABLE 6 Names of the different shaken bamboos and drums of the angklung ensemble

\begin{tabular}{|c|c|c|c|}
\hline & Symbol & $\begin{array}{l}\text { Van Zanten } \\
\text { 1995: } 523 \text { (with } \\
\text { corrections) }\end{array}$ & $\begin{array}{l}\text { Karamaén 2003 } \\
\text { (MD 2003-13) a } \\
\text { Anirah (A2016- }\end{array}$ \\
\hline & & $\begin{array}{l}\text { [shaken } \\
\text { bamboo] }\end{array}$ & \\
\hline 1 & $\mathrm{~L} 1$ & loér 1 & loér [also roél] \\
\hline 2 & $\mathrm{~L} 2$ & loér 2 & loér [also roél] \\
\hline 3 & $\mathrm{~T}$ & torolok & \\
\hline 4 & $\mathrm{IL}$ & indung leutik & \\
\hline 5 & $\mathrm{E}$ & éngklok & \\
\hline 6 & G & gunjing & \\
\hline 7 & $\mathrm{D}$ & dongdong & \\
\hline
\end{tabular}

$8 \quad \mathrm{R} \quad$ ringkung

$9 \quad$ IG indung gedé indung

[tuned drums]

$10 \mathrm{~K} \quad k e t u k$ [highest drum $]^{\text {b }}$

11 Ta talinting [medium drum]

12 B
bedug [lowest
drum]

[not in Inner Baduy

area], tuning same as

gunjing instrument

tuning same as indung

Rasudin 10 Dec 2013 
As far as I know all angklung sets in Kanékés are made by Inner Baduy, although it seems that Outer Baduy are also allowed to make angklung instruments. The makers use different kinds of bamboo for the pipes and the frames of the instrument: temen (Karamaén, A2003-2:5) or surat (Anirah, A2016-1: 65). Surat bamboo (awi surat) is also called andong, gedé or gombong bamboo. It is a thick kind of bamboo, also used for building houses. ${ }^{12}$ Budi $(2015: 18-19,184)$ reported that the angklung instruments in Kasepuhan Ciptagelar used to be made of gombong bamboo, but nowadays often the wulung or hideung (black) bamboo is used. ${ }^{13}$ Anirah told that he could make an angklung set of 9 instruments in three days, but before being used, the instruments should be given two months to stabilize the sound. An angklung set will last at least for ten years (A2016-1: 65). See some other information on making and playing Baduy angklung in Djoewisno (1988: 42-50) and Budi (2013) for some information on making angklung instruments in the nearby Ciptagelar.

The body of the Baduy drums consists of teluk (tesuk?) or nangka wood and the membranes are made of skin of the mencek (Indonesian: kijang, a small type of deer/roe) that is difficult to find nowadays. However, no other skin is allowed. ${ }^{14}$

The Baduy angklung is only played by men and boys of 6 to 7 years and older. It used to be the same in Kasepuhan Ciptagelar, however nowadays the angklung there may also be played by women and girls (Budi 2015: 17-18). The Baduy drums are played by adults, and also the dancers are adults. There may be 3, 5 or 7 dancers: always an odd number, larger than one.

For the fringes on top of angklung instruments the Baduy use pélah (kind of rattan/rotan) leaves and Djoewisno (1988: 47) mentioned that these are meant to protect against calamities: tumbal keselamatan. In the Kasepuhan Ciptagelar, about 4okm southeast of Kanékés, the angklung instruments are considered female objects and it is said that therefore they fix brushes or fringes (rarawis) on the top. The drums are considered to be male, because of the string keeping the membrane in place at the top (Budi 2015: 208-209).

In the construction of the Baduy angklung instruments, the vertical bamboo sticks of the frame are pierced and the horizontal sticks are put through this hole and thus pressed tight. In the Baduy angklung set that I bought in

12 The scientific name for surat bamboo is given as Gigantochloa verticillata (Willd.) Munro (Sastrapradja et al. 1977: 30-31; Stevens and Schmidgall-Tellings 2010). Eringa (1984) mentions that temen bamboo is very similar to tali bamboo: Gigantochloa apus (Bl. Ex Schult.f.) Kurz.

13 Gigantochloa atter (Hassk.) Kurz ex Munro (Sastrapradja et al. 1977: 12-13, 32-33).

14 See Anirah, A2o16-1: 65; Karamaén, A2003-2: 5 and interview on MD 2003-13, 12-12:40; Rasudin, A2013: 28. 

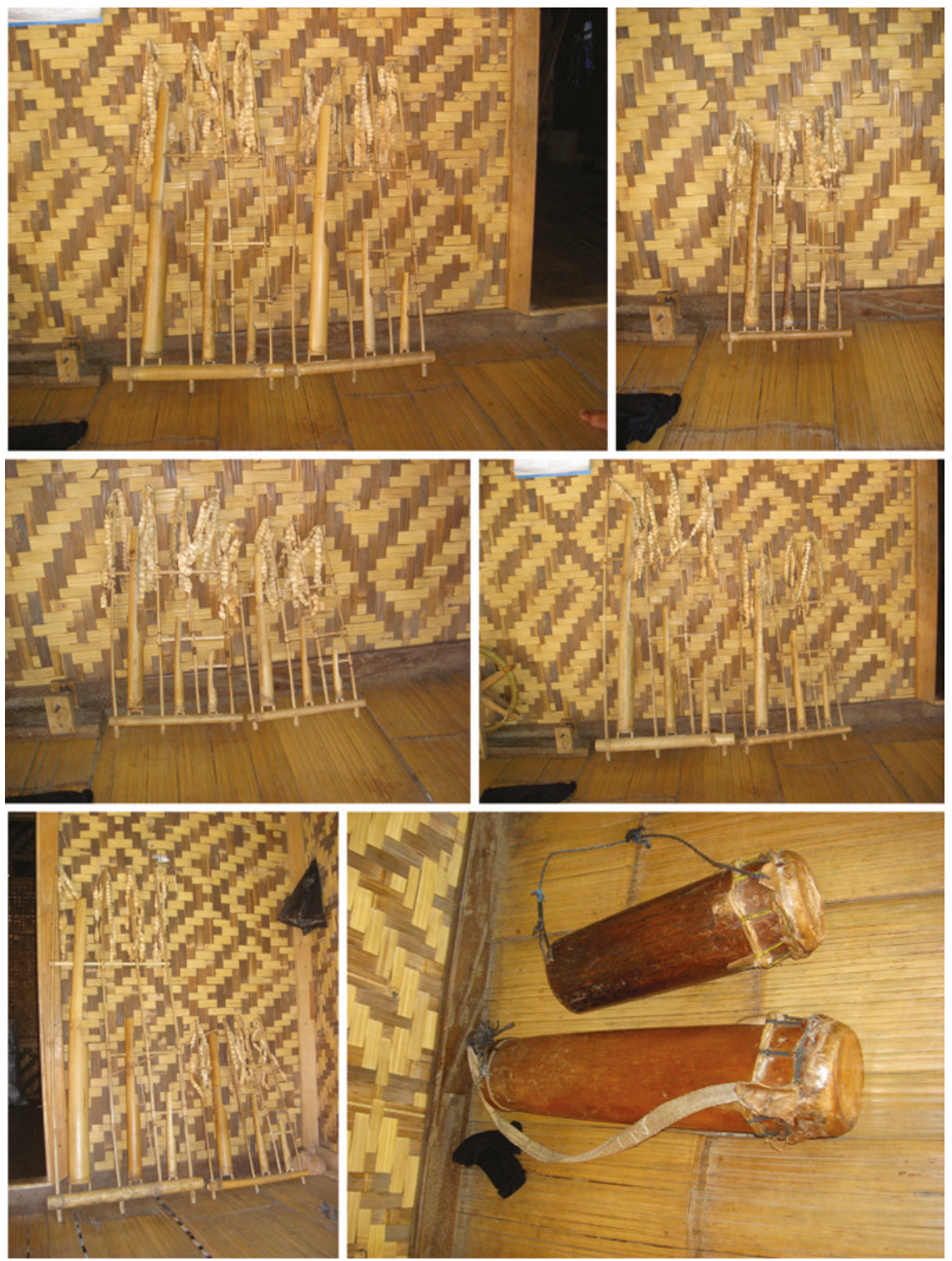

FIGURE 34 Angklung instruments of Rasudin in Kaduketug 1, 10 December 2013. Top-L to R: dongdong and gunjing, torolok; mid-L to R: loér 2 and loér 1, ringkung and éngklok; Bottom-L to R: indung gedé and indung leutik, bedug and smaller talinting

September 1976 rattan (hoé) was used for binding the horizontal and vertical pieces together (similarly in Ciptagelar: see Figure 3.14 in Budi 2015: 208). In the photographs of the angklung set of Rasudin in Kaduketug in December 2013 (Figure 34), it may be seen that the split vertical bamboo sticks are 


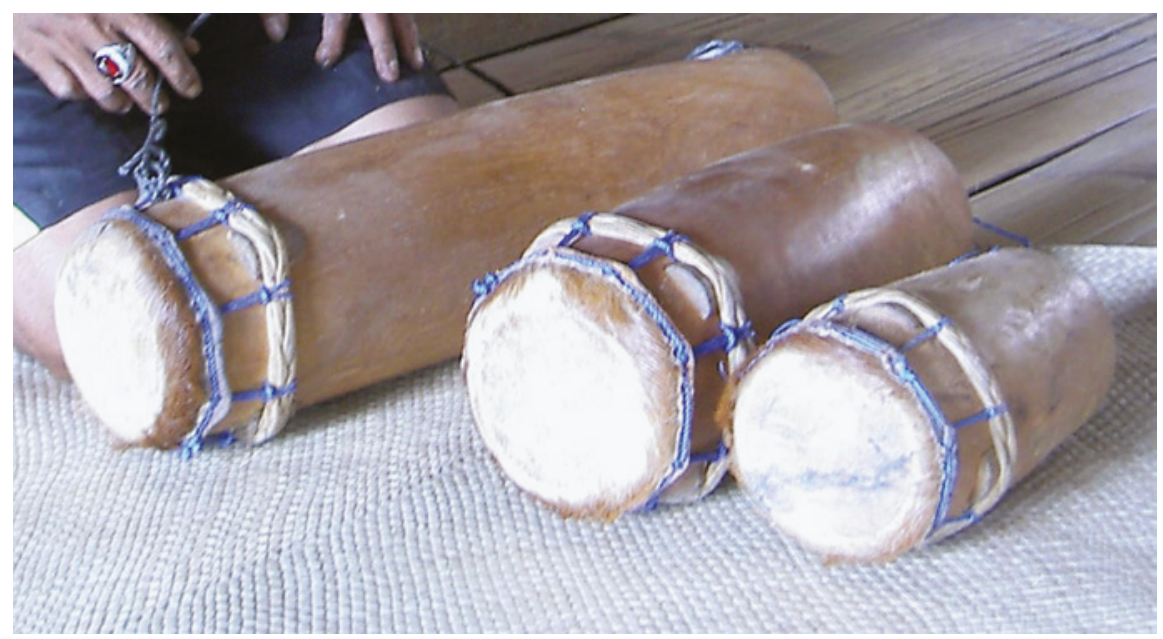

FIGURE 35 Three drums that accompany the nine shaken bamboos of the angklung set owned by jaro pamaréntah Saijah. From left to right: bedug, talinting and ketuk. Kaduketug 1, 1 July 2016

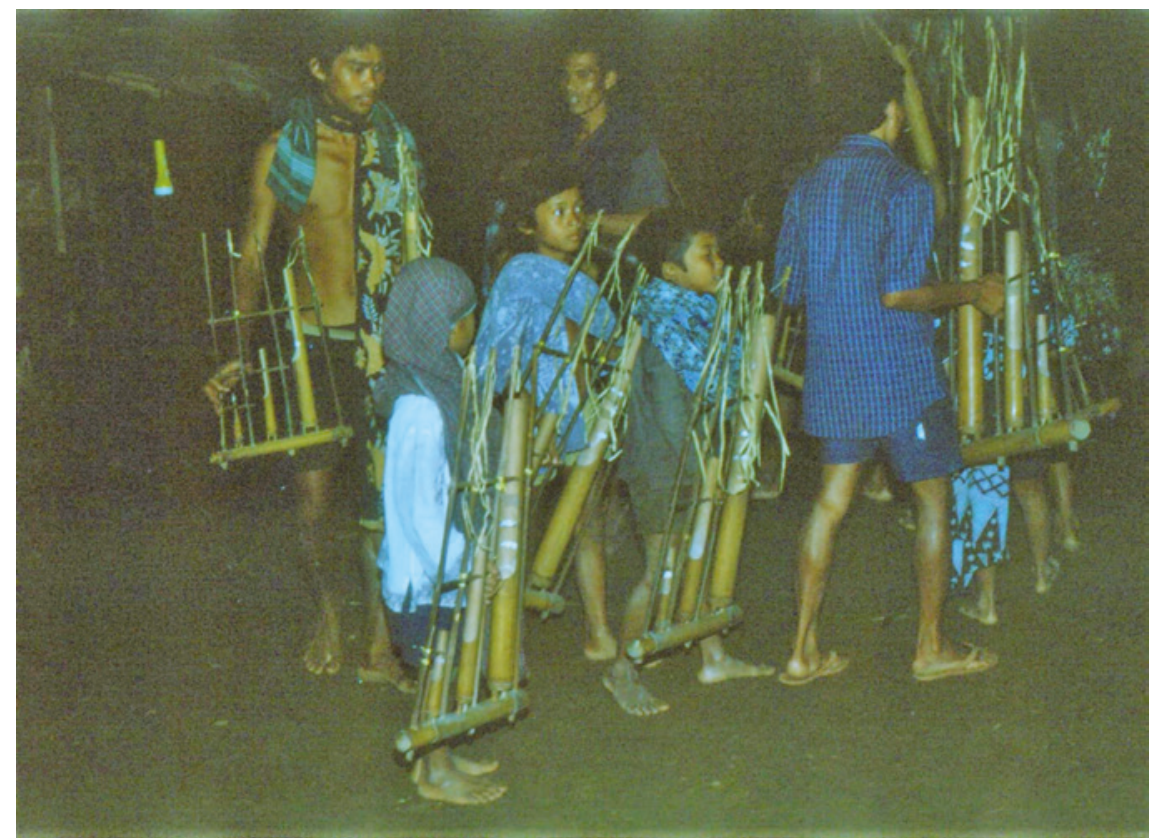

FIGURE 36 Baduy angklung played by boys and young men. Rehearsal in Kadujangkung, 15 October 1992 
strengthened with thread just above and below the hole for the vertical stick, preventing it from splitting further. I have no detailed information about the construction of the Baduy angklung instruments. See, for instance, Masunah (2003: 18-24) for a general description of this process in Sunda.

Budi (2015:183-211) offers a comprehensive description of the construction of the angklung instruments in Kasepuhan Ciptagelar, about 4okm southeast of Kanékés. There are two drums (dogdog lojor) and five angklung instruments, from high to low tones (frequencies): kirilik, kingking, inclok, panempas/ panembal, gonggong. The highest instrument (kirilik) is not always used, like in the song Adulilang for the rice planting ceremony, ngaseuk (Budi 2015: 148-149, 213, 232-233). In contrast to the Baduy angklung, the angklung dogdog lojor in Kasepuhan Ciptagelar is not only used for rice rituals, but also for events in a life cycle (tali paranti) like circumcisions and marriages and for 'religious ceremonies' (upacara keagamaan), like the Islamic Mulud, Lebaran Haji feasts and the ruat (ruwat) religious meals (Budi 2015: 174).

The Baduy angklung is in the first place connected to the planting of rice and keeping it healthy. In Section 4.2 I described the ritual 'engagement' of the goddess of rice, Nyi Pohaci Sang(h)iang Asri, to the earth Pertiwi and the ceremonial planting of rice the next morning on the Outer Baduy special rice field huma tuladan. However, angklung may also be used for entertainment, and in particular singing of the 4-line verses that are called susualan or sisindiran. This will be discussed in Chapter 7 .

In their book on several types of Sundanese angklung (Dogdog Lojor, Badud, Badeng, Buncis) Masunah and others emphasize that the rhythm of the angklung playing is more important than the melodic part and the singing (Masunah et al 2003-1: 59) and I think this also holds for the Baduy angklung for entertainment. Only in the angklung developed by Pa Daéng and Udjo Ngalagena in Bandung (Angklung Indonesia in Saung Angklung Udjo) in the 196os, which includes diatonic angklung and shows other Western influences, the melodic aspects became more important than the rhythmic section (Masunah et al 2003-1: 78).

Baduy angklung is also increasingly used for entertaining guests from outside Kanékés. I have commented on the angklung being put on the Representative List of the 2003 UNESCO convention for the safeguarding of the Intangible Cultural Heritage: there were several shortcomings in the Baduy data supplied to UNEsCo (Van Zanten 2012: 138-141; 2017: 93-94). Compare also Masunah and others (2003-1: 1-12), who note a general shift from the use of angklung in rice rituals towards entertainment and that around the year 2000 only few Sundanese people associated angklung with the growing of rice on dry fields (huma, ladang). 
TABLE 7 The interlocking playing by the three pairs of lowest Baduy angklung instruments

No.

beat 1 beat 2 beat 3 beat 4

$1 \quad$ indung gedé together with the indung $\mathrm{x}$ leutik

2 ringkung together with éngklok

3 dongdong together with gunjing

Musically all Baduy angklung songs used for susualan have a basic pattern of four time units that is played by the three pairs of instruments, mentioned in Table 7:

The different higher melodies are played by the loér 1, loér 2 and torolok instruments (A1992-1: 43). These three highest instruments produce a regular number of four notes per pulse/beat, because they are shaken fast: a tremolo. In my music transcriptions these rapid iterations of one note (and its octaves, with four notes per pulse) are indicated in the common way, that is, by two flags on the stem of the note. The six lowest instruments only produce one note per pulse/beat that is represented by a quarter note.

Music Transcription $\operatorname{Tr} 2$ represents the song Randa Ngéndong, played by the angklung group from Gajéboh and recorded in Jakarta in the night of 8-9 September $1976 .{ }^{15}$ It is a small section of 16 seconds taken from about the middle of the songs: from 2:12-2:27 after the start of the playing. In this transcription I only represented the fundamental tone on each instrument, produced by the largest tube. I used the following Western notes for the sounds of the instruments, from high (alit, leutik) to low (gedé): $\mathrm{c}^{2} \#$ for loér $1, \mathrm{~b}^{1}$ for loér $2, \mathrm{a}^{1}$

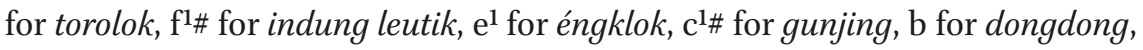
a for ringkung, $\mathrm{f}$ for indung gedé.

In Music Transcription Tr 2 the top line is for the three highest (alit, leutik) instruments that play the basic melody: loér 1 (L1: note $\left.\mathrm{c}^{2} \#\right)$, loér 2 (L2: note $\left.\mathrm{b}^{1}\right)$ and torolok (T: note $\left.\mathrm{a}^{1}\right)$. The third and last line is for the lowest instruments: dongdong (D: note b), ringkung (R: note a), indung gedé (IG: note f\#). The second line is for the three instruments that sound on the same beat as the lowest three instruments: indung leutik ( $\mathrm{IL}$ : note $\mathrm{f}^{\mathrm{l}} \#$, sounding together with indung gedé $\mathrm{f} \#$ ), éngklok ( $\mathrm{E}$ : note $\mathrm{e}^{1}$, sounding together with ringkung $\mathrm{a}^{1}$ )

15 I then lived in a house near the very busy Manggarai bus station. Only during midnight the noise of the traffic would not severely interfere with the music. 
and gunjing (G: note $\mathrm{c}^{1} \#$, sounding together with dongdong $\mathrm{b}$ ). On the recording used for this transcription $<\mathrm{AV}$ o1 $>$ the three highest and the three lowest tones may fairly clearly be heard. This is not the case with the middle tones, especially not those produced by the éngklok and gunjing. For these mid-tones I applied the information that these instruments play in pairs with the lowest three notes and at exactly the same speed.

As the basic structure of the three lowest instruments repeats itself every four beats (the ostinato pattern), in the transcription I have used one measure for each of these units. In the transcribed section there are about 120 beats per minute. However, the whole piece starts with a speed of about 70 beats per minute and it ends in the last 15 seconds with a speed of about 240 beats per minute. Rasudin, leader of the angklung group in Kaduketug 1, called the 'introductory section' to any piece of music burulung (A2013: 27). It is not clear to me how long this slower introduction lasts: is it just the first line in Music Transcription $\operatorname{Tr} 3$ that takes $6^{1 / 2}$ bars? The speeding-up of the last section of a song is called ngagubrugkeun and may last from a few seconds to several minutes. It is mostly longer if there are dancers with the group. During the fast playing at the end, the angklung players stand still and the dancers run around them, followed by the drummers, as described in Section 5.5 below and earlier in Van Zanten (1995: 536); listen also to <AVo4>, 70" and see the dancers and drum players in $\left\langle\mathrm{AVO}_{05}>\right.$, 2' 44 ".

Below I will describe the 'melodic structure' of Baduy angklung pieces played by the tremolos of the three highest instruments (loér 1, loér 2 and torolok). This 'basic melody' is played together with the 'ostinato patterns' consisting of four quavers, played by six lowest instruments described above. Note that Masunah and others (2003-1: 48-51, 67-72) give similar patterns played by the three to five lowest instruments in what they call the 'main melody' (melodi utama or melodi) for the angklung Badud in Ciamis (southeast from Bandung) and the angklung Buncis in Arjasari-Banjaran (southern part greater Bandung). According to these authors the high angklung instruments that play tremolos add 'ornaments' (hiasan) to the 'melody' played by the lowest instruments. These different terminologies need further investigation.

The whole angklung piece Randa Ngéndong lasts about 5'10". From Musical Transcription $\operatorname{Tr} 3$ it becomes clear that the three melodic instruments (loér 1 , loér 2 and torolok) play patterns that are 8 measures long (that is, 8x4 beats, or quaver notes) during the first half [o':0o"-2'43"] of the performance: repeated with some variations. For simplicity reasons, I have only written the tremolos on each quaver in the first line.

Comparing the corresponding bars in each line of Music Transcription Tr 3 , it is clear that each line presents the basic pattern and its variations of the 


\section{Randa Ngéndong}

Angklung Gajéboh - 1976

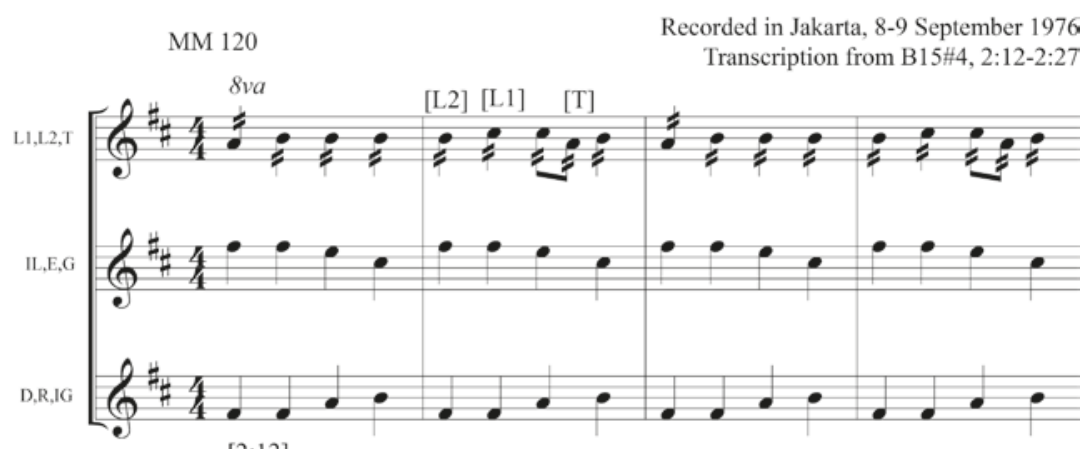

[2:12]

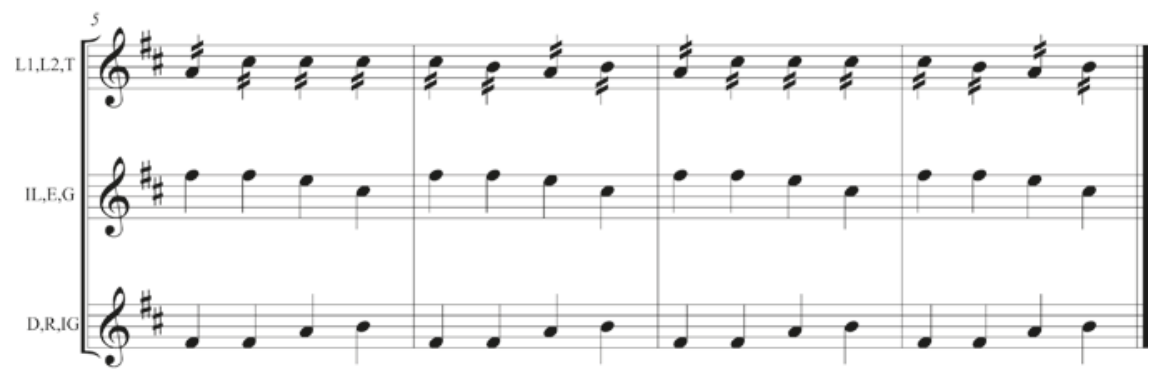

$[2: 27]$

MUSIC TRANSCRIPTION tr 2 Melodic structure of Randa Ngéndong by the Gajéboh angklung group, as played by the instruments loér 1 , loér 2 and torolok, and accompanied by the 4-beat patterns of the other six instruments, 8-9 September 1976. Listen to <AVo1>

song, consisting of eight bars in the transcription. Only the start in the first line is slightly shorter. The two loér notes $\left(\mathrm{c}^{2} \#\right.$ and $\left.\mathrm{b}^{1}\right)$ are regularly stressed by sounding for 2 or $4-4 \frac{1}{2}$ beats (that is, 8 or $16-18$ tremolo of sixteenth notes, or demisemiquavers); the torolok note $\left(\mathrm{a}^{1}\right)$ never lasts longer than one beat.

Similarly, the melodic structure of the angklung piece Ceuk Arileu, played by the three highest instruments, is given in Music Transcription $\operatorname{Tr} 4$ below. Listen to $<\mathrm{AV}_{\mathrm{O}}>>$ that gives about the first $1^{1 / 2}$ minutes or the second line repeated three times. I consider the first line to be the 'beginning' of the piece; it consists of about the seven bars 2 to 8 . As from the second line the melodic pattern of 8 bars is repeated without variation until the end of the piece at 5'19". Hence only the beginning of the piece is slightly different from what follows in the second line that is repeated until the end of the song. In this melodic pattern (bars numbered 9-16) both notes $\mathrm{b}^{1}$ and $\mathrm{c}^{2} \#$ are stressed. 


\section{Melodic structure Randa Ngéndong}

by three highest angklung instruments: loér 1 (L1), loér 2 (L2) and torolok (T) playing tremolos

Recorded in Jakarta, 8-9 September 1976

Transcribed from B15\#4, 00-2:34

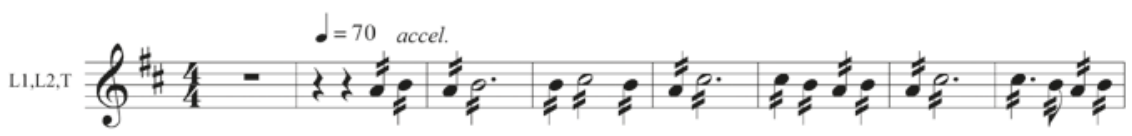

[0"]

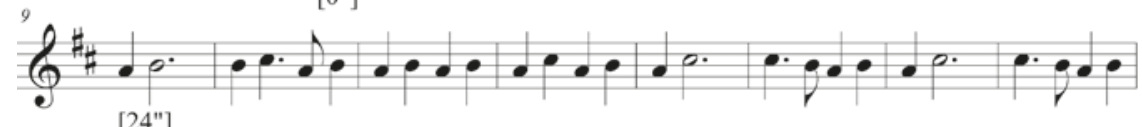

[24"]

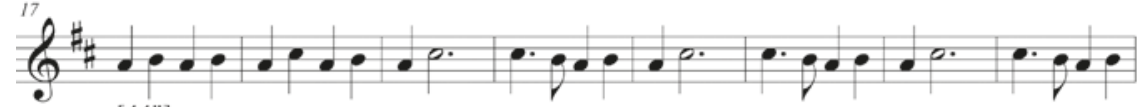

[44"]

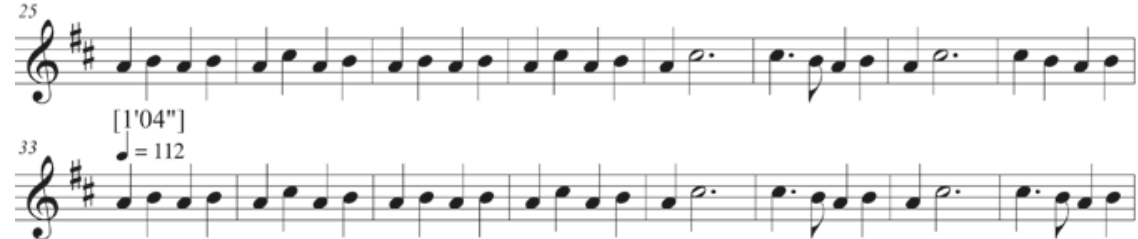

[1'22"]

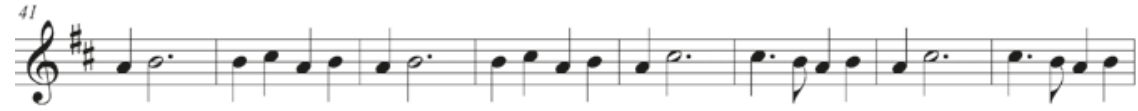

[1'39"]

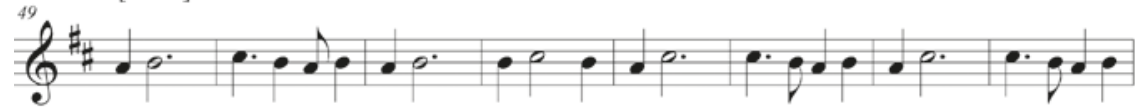

[1'56"]

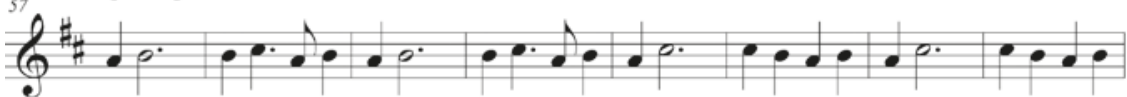

[2'12"]

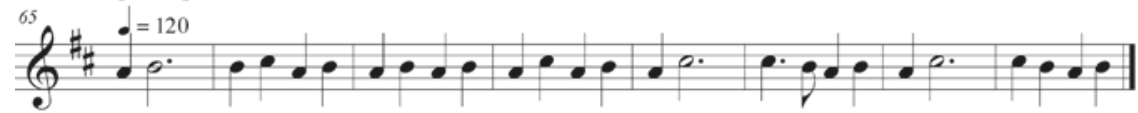

[2'27"]

[2:43"]

MUSIC TRANSCRIPTION TR 3 Melodic structure of the angklung piece Randa Ngéndong by the Gajéboh group, as played by the instruments loér 1, loér 2 and torolok, September 1976. < AVo2>

The speed increases from about 60 at the beginning to go beats per minute at o' 49 " at the end of line 2. At 1'30" after the beginning the speed has increased to 110 beats per minute. After 4'25" the fast playing for ending the song (ngagubrugkeun) starts and lasts for about one minute at a speed of 144 beats per 


\section{Melodic structure Ceuk Arileu}

by three highest angklung instruments: loér I (L1), loér (L2), torolok (T) playing tremolos

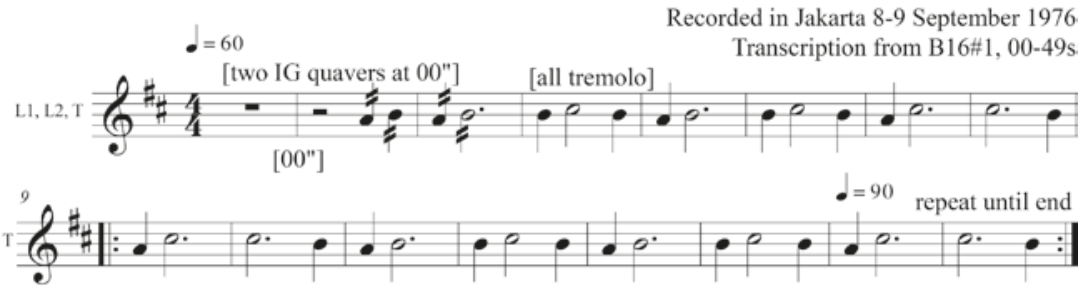

[49"]
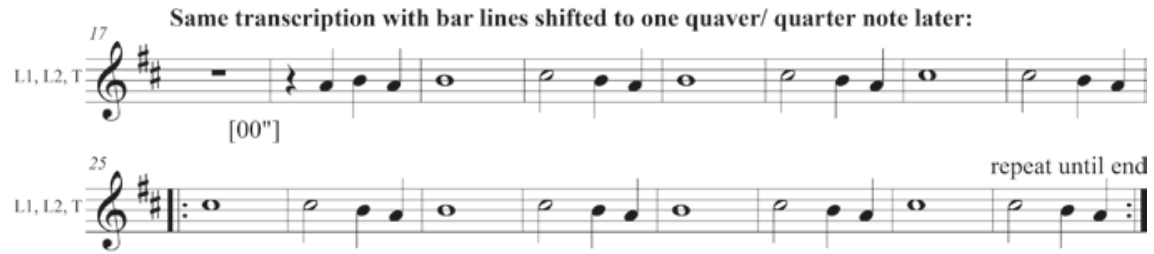

[49"]

MUSiC TRANSCRIPTION TR 4 Melodic structure of the angklung piece Ceuk Arileu by the Gajéboh group, as played by the instruments loér 1 , loér 2 and torolok, September 1976. Two ways of transcription. Listen to $<\mathrm{AV}$ O3 $>$

minute; listen to $<\mathrm{AV}$ o4 $>$ that starts about 4:o9 after the beginning and ends at 5:19 of the piece Ceuk Arileu.

The second half of $\operatorname{Tr} 4$ gives exactly the same as the first transcription, except that the bar lines were shifted to one quaver ('beat', quarter note) later. In the first two lines the 4-beat bars were taken to coincide with the basic ostinato pattern in the six lowest instruments, as given in Table 7 above:

beat 1: indung gedé + indung leutik;

beat 2: indung gedé + indung leutik;

beat 3: ringkung + éngklok;

beat 4: dongdong + gunjing.

If we shift the bar lines to one beat later, as happened in bars 17-32 of $\operatorname{Tr} 4$, it has the advantage that the structure becomes 'clearer' in staff notation. However, this second transcription hides the syncopation ('off-beat playing') shown in the first transcription and which may be a wanted characteristic of the music. We need further information on this.

During the ngarérémokeun ritual that I witnessed in Kadujangkung on 2223 October 1992, the angklung of this hamlet played much slower: about 42 beats (quaver notes) per minute at the start of the evening, around 19:15-19:45 
(DAT 92-10, beginning). The lower three instruments played the same ostinato pattern of four notes that has been given above for the Randa Ngéndong and Ceuk Arileu transcriptions of 1976. In October 1992 the angklung also accompanied singing: solo and chorus singing; at this moment there were no dancers; see further Section 4.2 and Van Zanten (1995).

\section{$5 \cdot 3 \quad$ Keromong (gamelan)}

Baduy call their set of bronze idiophones keromong, goong or lénong, but also by the general Indonesian name gamelan. In current practice keromong seems to be most commonly used, and that word also indicates one of the instruments in the ensemble. The ensemble also includes other instruments like the gambang xylophone, or the four-string violin (viol, biola). Like most Sundanese gamelan ensembles the Baduy keromong consists of only a few instruments:

- Two caning: metallophones with six keys, sometimes five keys, called saron elsewhere in Java;

- One optional panerus metallophone with six keys and tuned one octave lower than the caning (A2016-1: 29);

- Keromong: set of ten bronze kettles resting on a horizontal frame, called bonang elsewhere in Java;

- Optional kenong: set of five bronze kettles resting on a horizontal frame (in Gajéboh, 1976, see Figure 37), or kempul: one gong held in the hand (in Kompol, 1976; see <AVo6 >: Keromong Kompol playing Kembang Beureum; film 2m3os);

- Gambang: xylophone with 14 to 20 keys; since about 2005-2010 an extra gambang xylophone was added to reproduce the drum patterns that are used in Sundanese gamelan outside the Baduy area: a gambang kendang;

- Kecemprés or kecrék: two cymbals, held on top of each other and struck with a stick or just hitting each other;

- One small and one large gong;

- A four-string violin (viol, biola) is optional; before the 1980s the rebab (twostringed bowed lute) seemed to be commonly used, instead of the viol.

See pictures of most of the bronze instruments and the xylophone in Figures 37,39 and 40.

In 1995, I reported to have seen the violins, but not hearing them being played with the keromong. In the recordings made in the 196os by Bernard Suryabrata, a copy of which is kept at Cornell University, the Baduy gamelan is played with both rebab and suling (lamus). This also happens in central Java, but the rebab-suling combination is no longer (or rarely?) used in present-day Sundanese gamelan: generally speaking, the rebab is only used in the gamelan 
saléndro, and the suling only in the gamelan degung (see also Van Zanten 1989: 81, 103; 1995: 525-527).

I recorded keromong with rebab and female vocalists in Gajéboh in June 1976; listen to $<A V$ o7 $>$ : Keromong Gajeboh playing Kembang Beureum - 1976; B2-3 Audio 1m49s. After this time I did not record or hear about a rebab with the keromong. It is said that in current practice the rebab is no longer allowed by the spiritual leaders. Since the 199os it is rather a viol and/or a gambang xylophone that are used for the melodic parts of the gamelan music. In October 1992 Ojél, leader of the angklung ensemble in Kadujangkung, confirmed that there was no rebab in Kanékés. Instead, he said, you could use a rendo or a viol in the gamelan (A1992-1: 38). It may be that (shortly?) after my recording in 1976 the rebab was no longer allowed in the Baduy area (rebab tidak boleh masuk daerah Baduy), as Satra told me in April 2003 and Anirah in 2016 (A2003-2: 4; A2016-1: 63). I have never heard that a rendo has been used in the keromong ensemble. I do not know the reasons why the rebab is not allowed in Kanékés. However, the main reason might be its association with Islam: the instrument spread with Islamic expansion from Arab countries through Persia, Afghanistan, and India to Southeast Asia; see also Van Zanten (1989: 107-110).

This example of the rebab seems to indicate a general sequence of events: Outer Baduy trying to introduce a new element that will be tolerated for some time, because the spiritual leaders do not yet know whether it should be allowed or not according to their religion, and then some time later it is decided that the new element will be forbidden. This happened, for instance, with the growing of clove trees that became big business in several parts of west Java in the 1970s. In 1976 I saw many young clove trees in Kanékés. When the trees were about to give fruit, the spiritual leaders decided that cloves were forbidden in Kanékés and all (most) clove trees were cut. Such measures obviously lead to tensions between the Outer and Inner Baduy groups. In 2016 I noticed cloves being dried in the sun in several Kanékés hamlets; see, for instance Figure 33. Baduy people explained that these cloves were bought outside Kanékés, then dried inside Kanékés and sold outside Kanékés. Baduy themselves and former Baduy have described such behaviour as 'hypocritical' to me.

Only Outer Baduy play keromong; not the Inner Baduy. Moreover, not all hamlets in the Outer Baduy area of Kanékés are allowed to have a keromong; this is restricted to about one third of the 6o hamlets lying in the northern part of Kanékés. In March 2003 (Sapin) and December 2013 (Rasudin) gave a list of 16 Baduy hamlets that possess a keromong: Balimbing, Batara, Cipalér 1, Cipalér 2, Cisaban, Cisaban 2, Ciwaringin, Gajéboh, Kadujangkung, Kaduketug 1, Kaduketug Gedé, Kadukohak, Karahkal, Panyerangan (?), Sorokokod and the dangka hamlet Cepakbuah (?) near Kompol. Other hamlets that are allowed to 

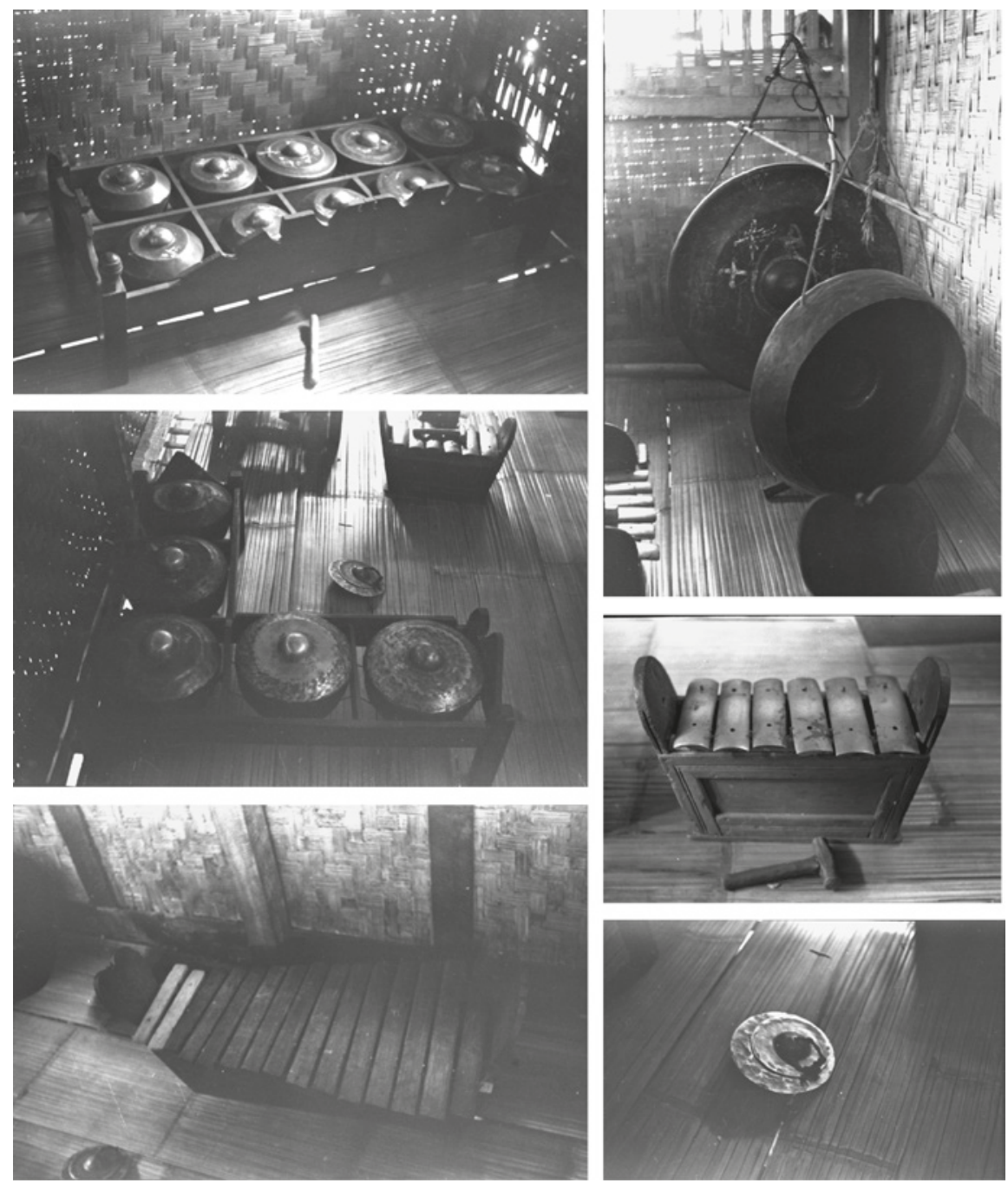

FIGURE 37 Instruments of the Baduy keromong recorded in Gajéboh, Kanékés on 12 June 1976

have a keromong, but do not have one are: Cicakal Girang, Cigula, Cipondok, Kadu Gedé, and Maréngo.

In July 2016 the tanggungan jaro duabelas Saidi and Ayah Anirah told that the keromong were only allowed in hamlets that were 'sufficiently' north from the Inner Baduy hamlets Cibéo and Cikartawana; the keromong playing should not be heard in those hamlets. This means that the border is about the west-east line from Cipalér/Cicakal Girang to Cisaban. Also the hamlets Cicatang 1-2, Cibongkok, Cikopéng and Kaduketer 1-2, although lying a little north of this line, 


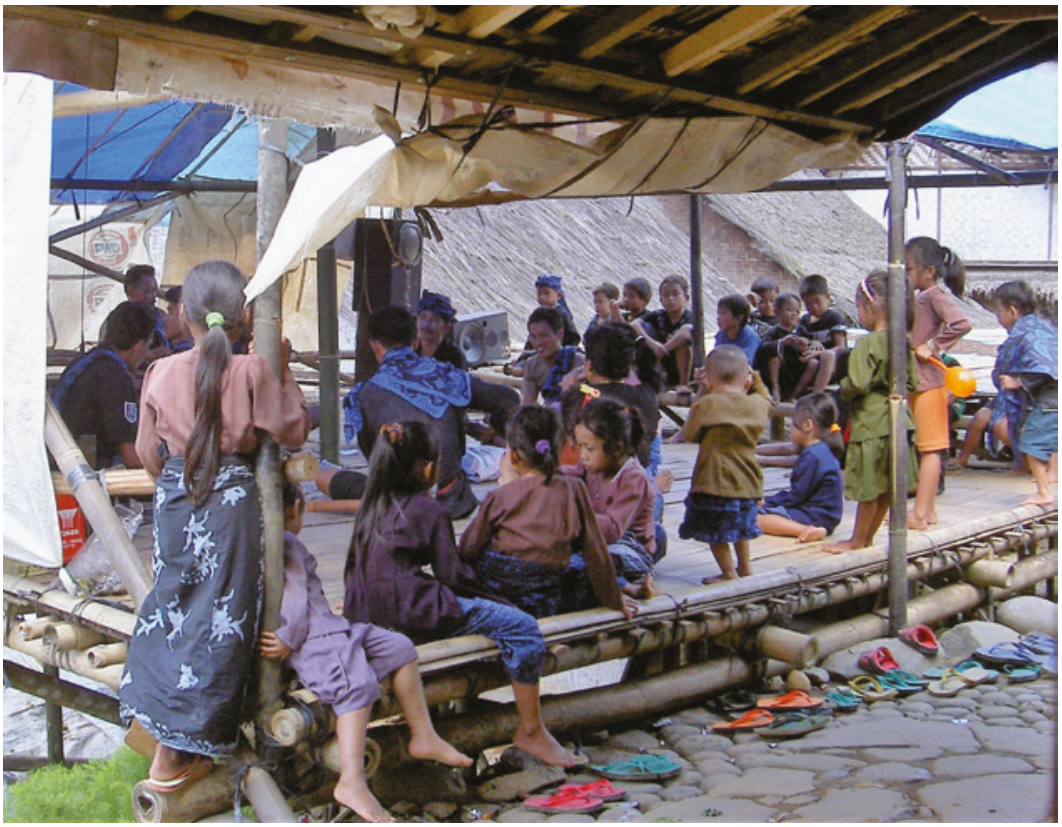

FIGURE 38 Children on stage with the keromong ensemble playing on the second day of the three-day circumcision ritual in Cicakal Leuwi Buleud, noon time, 4 July 2016

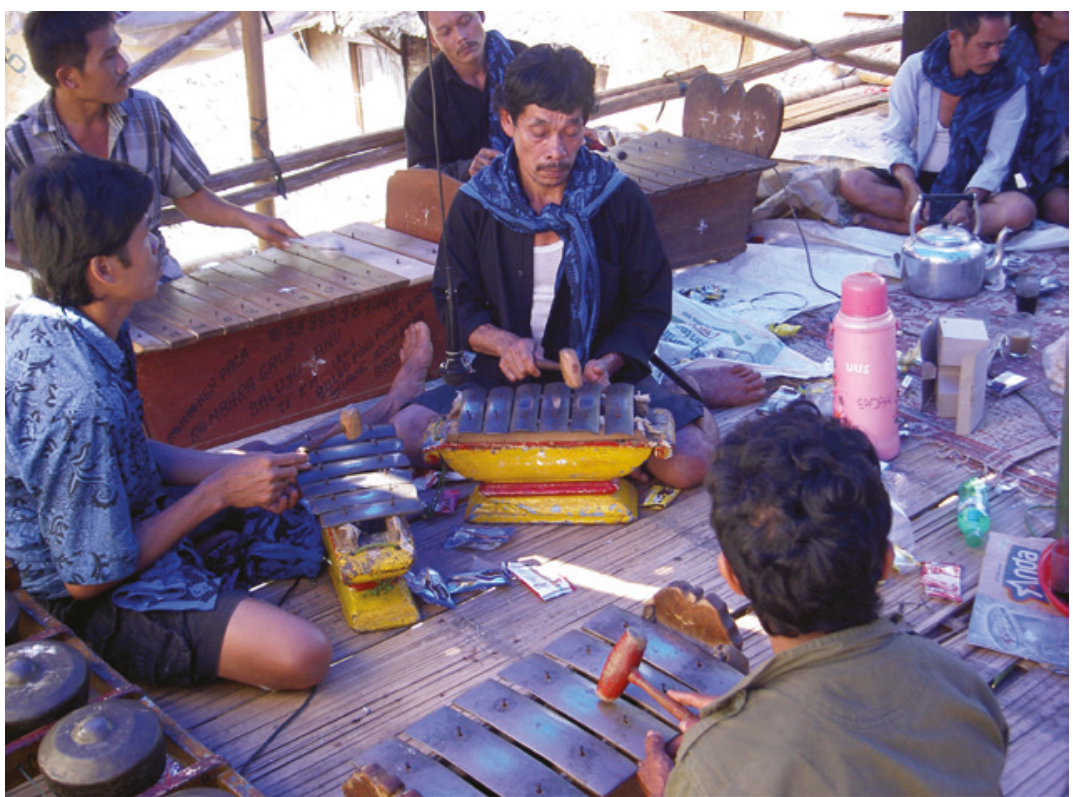

FIGURE 39 Keromong instruments, two caning, one panerus and two gambang, played on last morning of the three-day circumcision ritual in Cicakal Leuwi Buleud, 5July 2016 


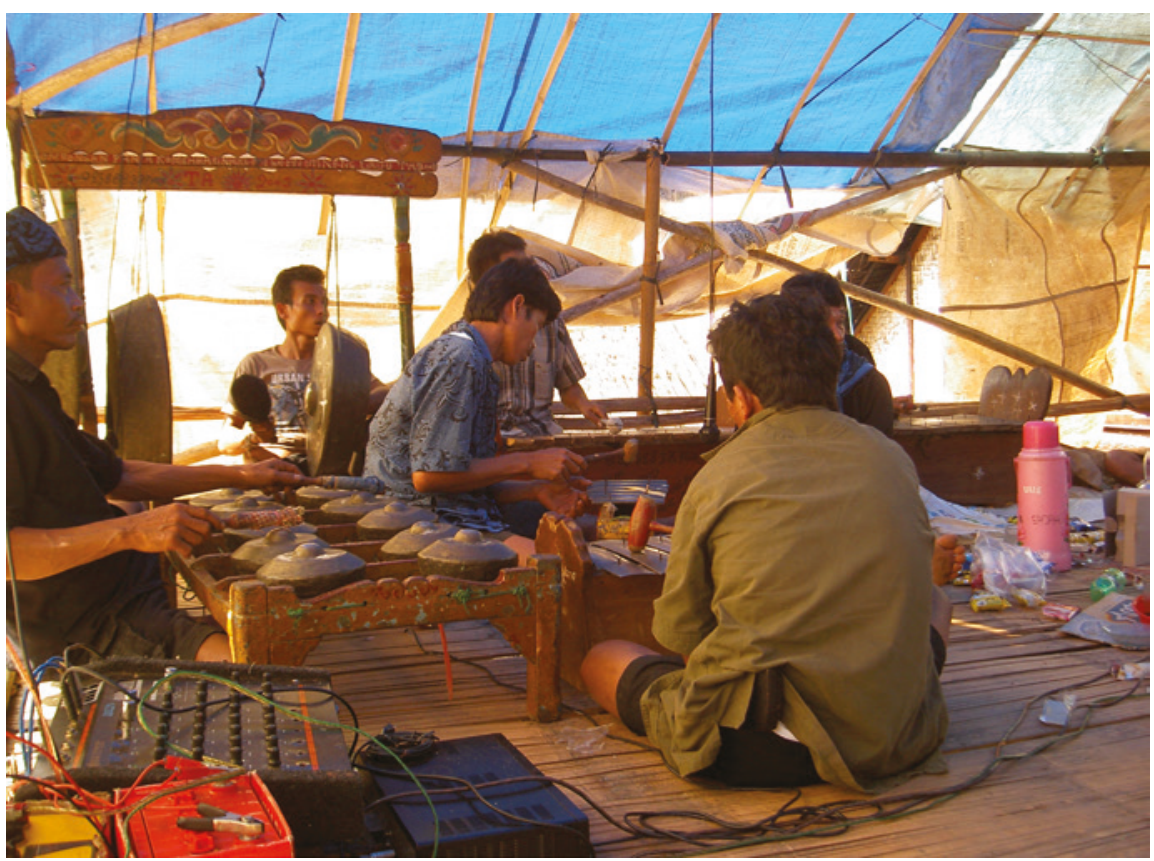

FIGURE 40 Keromong instruments playing on the last morning of the three-day circumcision ritual with sound amplification in Cicakal Leuwi Buleud, 5 July 2016

are not allowed to have keromong. I suppose that this is because those hamlets lie relatively high above sea level, and the sound of a keromong being played there would possibly be heard in Cibéo and Cikartawana. Ayah Anirah told that before the time of jaro pamaréntah Daénah (1997-2015) there used to be a keromong set in Kaduketer, something that is no longer allowed nowadays. ${ }^{16} \mathrm{He}$ added that the spiritual leaders (puun) should always give permission to play the keromong in a certain hamlet. In July 2016 I took photographs of the keromong that was owned by the Cicakal Leuwi Buleud community, but not listed by Rasudin. See Figures 16, 38-40; A1992-1: 31; A2003-1, 11, 20-21; A2014-1: 36-38; A2016-1: 24, 60, 62). Notice that this keromong also had two xylophones.

The sets of bronze instruments of the keromong are not made by the Baduy themselves, but bought in west Java outside Kanékés. This is also an indication of the musical relation between the Baduy and the surrounding Sundanese. The instruments made of wood (xylophones, violins) or bamboo (flutes) are mostly made by the Baduy themselves.

16 I suppose this might also have been caused by the use of amplification of keromong ensembles that started around 2010: the sound carried farther than before; see also Section 4.5. 
The tuning of the keromong instruments is like the angklung and may be called 'equidistant pentatonic', that is a kind of saléndro/slendro. In 1992 jaro pamaréntah Asrab said that the tuning of a gamelan used for the wayang golék performances outside Kanékés, that is, in saléndro tuning, was in accordance to the Baduy taste ('bekas suara golék, cocok untuk Baduy', A1992-1: 40). For finetuning of the bronze keromong instruments the Baduy use wax (malam), like in the other parts of Java (A2014-1: 39).

Keromong (goong) ensembles are metaphors for kingdoms or kings, and Geise (1952: 115) mentions several names of these goong ensembles. Section 6.5 will discuss this theme in some more detail. Sardi from Cikarého, Kompol, mentioned that before playing the keromong at an official occasion there would be an offering (sasajén): parawantén goong (A2014-1: 11).

\subsection{The History of a Baduy Gamelan between 1976 and 2019}

The history of the gamelan that I bought in 1976 and a few years later returned to the Baduy community is presented here, because it opened my eyes for several aspects of the Baduy society in the wider context of west Java and Indonesia. The gamelan was kept in my house in Indonesia between April 1976 and July 1979, because I was its 'owner'. Parts of the history of this gamelan presented in this section were published in Van Zanten (2004) and Van Zanten (2009), however, here I have included more details and new developments after my visits to the Baduy area in 2013, 2014 and 2016, and personal communication from my assistant Mumu until November 2019. In Van Zanten (2004: 143-145) the gamelan was mentioned because of its role in the cultural politics of the local authorities: Baduy and people of Baduy descent had complained about the authorities' attempts to have this gamelan transferred to the kabupaten Lebak in Rangkasbitung. The gamelan was also mentioned in Van Zanten (2009: 299-302), where I tried to show the complexities of intangible cultural heritage and intellectual property rights: 'prior informed consent' of a community is necessary, but not enough.

From February 1976 to August 1979 I worked at the Faculty for Social Sciences of the University of Indonesia in Jakarta. In April 1976 I bought a small old gamelan from the Baduy indigenous group for Rp 500 ooo (then about us\$ $1200, € 1120$ ). The set of instruments was offered for sale to me in Jakarta by the Baduy official Talsim (see his photograph in Figure 3), because the owner had died and the family needed money to pay their debts, he said. I was interested in Baduy music, as I had already been planning to make audio-visual recordings, but had no real interest in purchasing a gamelan. However, at that time I felt, it would be better to buy the gamelan myself than to allow a tourist unfamiliar with Baduy music to buy it. 
The negotiations with Talsim took place at the Faculty of Arts of the National University, stationed in Jatinegara, Jakarta and managed by Bernard Suryabrata (1926-1986). At that time I had just arrived a few months earlier in Jakarta and taken lessons on the kacapi by the kacapi-suling player Suleiman Danuwidjaja at the Faculty of Arts. There we arranged an interview with Talsim about the Baduy gamelan. The interviewer was Uk Sukaya, one of the musicians working at the Faculty of Arts, and further Bernard Suryabrata and I were present during this interview. I recorded this interview on audio tape (Tape B1, item 1, April-June 1976). Below I will first summarize this interview and later comment on it.

Talsim told that the Baduy gamelan would be played only during the three Baduy months Kalima, Kanem and Kapitu (roughly May-July). After this gamelan season, the angklung would be played. Now the kawalu fasting period had just come to an end and the Baduy were preparing for the ngalaksa [and séba] rituals. When 'the tasks of the puun spiritual leaders were done' there would be the ceremonial/communal rice pounding (gendék). The gamelan would only be played during the weddings (kawinan) and circumcisions (sunatan) that would be announced by the communal pounding of rice (gendék).

With the other instruments (one keromong, two caning, two large gongs, one kecerés or kecemprés and two kempul) there also was a small gong (bendé; see Figure 42). Answering a question by Suryabrata, Talsim confirmed that this bendé gong was not included in other Baduy gamelan and in this respect this gamelan set of instruments was special. ${ }^{17} \mathrm{He}$ added that this was the first time that a Baduy gamelan was sold to an outsider and in fact Talsim had intended to sell the gamelan to Bernard Suryabrata, who was known to the Baduy, because he had recorded their music already. However, [as Suryabrata was not interested or could not afford to pay the price?] it would now go to a foreign country.

The gamelan was estimated to date back at least to the first half of the nineteenth century, because it had been in the Baduy family for four generations. According to Talsim the instruments were made by a smith in Kanékés and tuned according to the pélog tone system. Suryabrata expressed his surprise that it was tuned in pélog, because most Baduy gamelan are tuned to the saléndro tone system. He asked Talsim whether this was a gamelan panggung (a 'stage' gamelan), meaning that it was related to the aristocracy, and Talsim confirmed this. This gamelan was to be played on a 'stage' (panggung) and not 'on the ground' (ditaneuh).

17 The small bendé gong with diameter about $40-60 \mathrm{~cm}$ is regularly mentioned in the pantun stories and the Old Sundanese manuscripts. In the past the bendé were used for official announcements of the court (Van Zanten 1989:33, 82); see also Section 3.1 above. Nowadays it is used in the pencak silat music in West Java (Soepandi 1995b: 39; Pätzold 2000: 76). 
So far this (recorded) interview with Talsim at the time I bought this Baduy gamelan in April 1976. The small gamelan stayed in my house in Jakarta and later in Cisalak during more than three years, without being played. When I planned to leave Indonesia in July 1979, I needed to decide what to do with it. I did not want to export the gamelan, and most probably I would not have been permitted to do so by the Indonesian government, as the gamelan was old. The second possibility was to donate it to the gamelan museum in Subang, West Java. Then it would probably not be played, which I did not want. Hence I presented this gamelan to Samin, secular village head (jaro pamaréntah) of Kanékés, as a representative of the Baduy people, with the hope that it would be played again by them. The village head came to my house in Cisalak to collect the gamelan, and we made a simple agreement/contract on paper that stated that this gamelan was returned to the Baduy community with the sole condition that it could never be sold again to outsiders. A copy of this contract is presented in Figure 41 and the translation of it reads: ${ }^{18}$

Contract ['letter of agreement']. This contract is made by us, Samin, head of Kanékés village, and Wim van Zanten of the Faculty of Social Sciences, University of Indonesia. Mr. Wim van Zanten has a gamelan that came from the Baduy community, now returned to the Baduy community, with the condition that this gamelan will not be sold again to other people. That means, this gamelan will be owned by the whole Baduy community that is represented by Samin, village head of Kanékés.

The village head of Kanékés may decide who shall be using the gamelan. This gamelan consists of one keromong, two caning, two gongs, one bendé, one kecerés and two kempul.

Cisalak, Cimanggis, Bogor

17 July 1979

[signature]

witness: Mr. Jakaria from Serpong

[signature]

Head of Kanékés village: Samin

[signature]

Wim van Zanten

18 The witness that signed this contract, Mr. Jakaria, was the driver employed in the Social Sciences project (RUL 27) between Leiden University and the Universitas Indonesia in which I was involved. 


\section{Surat perianilan}
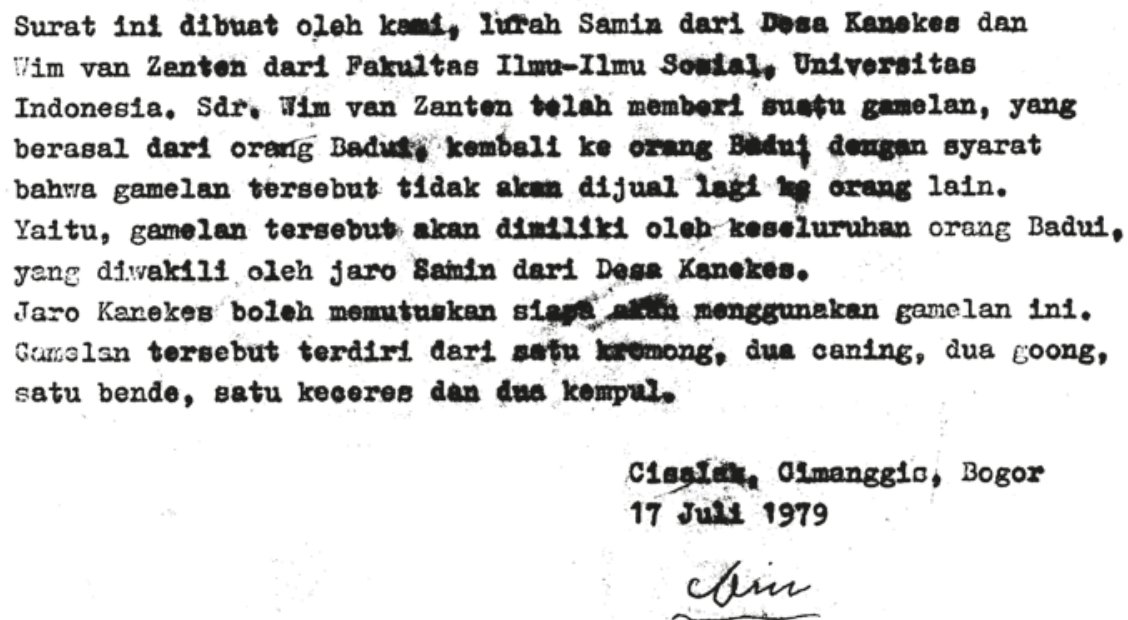

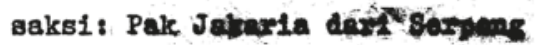

Juso Kanekest Saidn
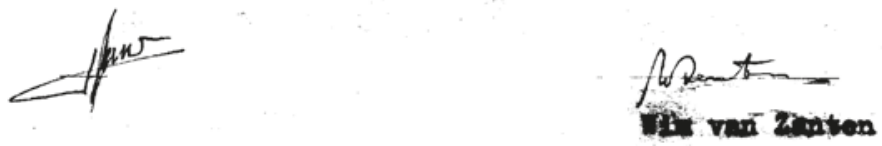

FIGURE 41 Agreement/contract about the gamelan returned to the Baduy community by the present author in July 1979

I did not return to the Baduy area until 1992. Samin, the former village head of Kanékés, had died in December 1991, and the gamelan instruments were no longer played. It was not possible to play the gamelan, because the different instruments were not kept together in one place, but were divided between the houses of two of Samin's sons, who lived in villages outside the Baduy area (Narja in Cipangembar and eldest son Nalim in Margaluyu). The sons remembered that I had presented the gamelan to their father, but they did not know anything about the conditions. They did not have a copy of my contract with their father (Figure 41). As mentioned already in Section 3.5, the sons also told me that they were put under great pressure to give the gamelan to the Regent of the Lebak Regency in Rangkasbitung, as had happened before with other Baduy instruments. I made clear to Narja and Nalim, that my intention had been to have the gamelan played by the Baduy people, and that I had returned it to the Baduy community, with the sole condition that it could not be sold again or disappear from the Baduy area. I asked for the gamelan, now in the resettlement area, to be returned to Kanékés village, which eventually happened at the end of 2002 . 
Since the end of 2002 the gamelan was kept by the family of Narja and Nalim living in the hamlet Kadujangkung, Kanékés. In an interview with Narja at his house in Cipangembar on 31 March 2003 he asked whether the gamelan could stay in Kadujangkung. I answered that this was no problem to me, as long as it would also be played there. This was my main concern: the gamelan should be used again in Kanékés. It was up to the Baduy officials in which hamlet the gamelan that I considered to be a communal property would be stationed and played. Anyway, the seat of the jaro pamaréntah in Kaduketug was very near to the hamlet Kadujangkung. The gamelan could easily be transported to Kaduketug if needed there. Narja asked me to tell the same to the jaro pamaréntah. His plea for Kadujangkung was apparently instigated because he considered many present Baduy leaders materialistic: they received money from the government, not for the Baduy, but for themselves (A2003-1: 54).

I saw the gamelan in Kadujangkung during my visit in April 2003, the first one after my 1992 visit to Kanékés and taking place in the fasting period ( $k a-$ walu) in which no gamelan could be played. By that time, the wooden frames for the different gongs and metallophones had wasted away and I donated Rp 600,000 (about $€ 65$, Us $\$ 71$ ) to the caretaker Arpani/Anik, grandson of jaro pamaréntah Samin, to have new ones made (A2003-2: 2). The gamelan would be played in the first coming gamelan season of June-August 2003 they said.

On my return ten years later, I saw the gamelan stored in Kadujangkung in December 2013 and made photographs of it. At that time we also visited Aki Armad, earlier called (Ayah) Hamdan, brother-in-law of Narja and Nalim. I had recorded and interviewed Aki Armad/Hamdan several times since 1976. Aki Armad told me that there was one problem with the gamelan that I had returned: it was tuned in pélog and they did not like that, because Baduy gamelan were usually tuned differently (A2013: 47-48). I told him that the gamelan was no longer my property and that they could re-tune the gamelan, if they wanted this. I expressed my hope that the tuning would be done by someone knowledgeable about Baduy gamelan. Aki Armad then also told that Saidi was now responsible for organizational matters concerning the gamelan. This had also been said by the pantun storyteller Arwa (see photograph in Van Zanten 2016: 419) a few days earlier. ${ }^{19}$ Later the pantun storyteller Ayah Anirah told that he had been responsible for the spiritual side of the gamelan since it was returned to Kadujangkung in 2002 (A2014-1: 23; A2016-1: 45). Each season

\footnotetext{
19 I assume, Aki Armad and Ayah Arwa meant the tanggungan jaro duabelas Saidi, living in the nearby Kaduketer 2.
} 
he had 'inaugurated' the gamelan with the offering of a chicken and prayers (secara batin).

When I visited Kanékés again in May-June 2014, the caretaker for the gamelan and Samin's grandson, Anik, told me that he thought the gamelan should be kept at a more official place. I replied that this seemed a good idea, if they wanted this. However, I was no longer the owner, and I did not want to make a decision about this. It was up to the Baduy community to decide. I had only set one condition, namely that the gamelan should stay in Kanékés as it was communal property of the Baduy. At this time I also discussed this matter of where the gamelan should be stationed with the former jaro pamaréntah Asrab and the village secretary Sapin. Both agreed that it would be a good idea to move the gamelan to the official residence of the jaro pamaréntah in Kaduketug, a house that had been built when jaro Asrab was in office in 1992. If stationed there, it would be attached to the official house for the jaro pamaréntah, and it would be easier to show that is was communal property. Jaro Asrab suggested that it would be best if I wrote a letter about this.

This happened in 2016. On 1 July 2016 I personally handed a letter, dated 27 June 2016, to the village head (jaro pamaréntah) of Kanékés. It was directed to the village head and immediately read by Saijah and the former village secretary Sapin. In this letter I wrote about the gamelan I had handed over to Samin in July 1979

I do not want to interfere with the question where this gamelan should be stored and played in Kanékés. The most important for me is that I ask the Baduy community to look after this gamelan and play it in Kanékés village.

However, if there is confusion about the question where the gamelan should be kept, I suggest that it is at the house of the jaro pamaréntah (or nearby this official house in Kaduketug), because as a matter of fact the gamelan is under the jurisdiction of the jaro pamaréntah and other leaders of Kanékés. When stored in the official house of the jaro pamaréntah, it will be clearer that this gamelan does not belong to one person, one family or one Baduy hamlet, but is owned by the entire Kanékés community that is represented by the village head. ${ }^{20}$

$20 \quad$ '... sebenarnya saya tidak ingin campur tangan dengan persoalan di mana gamelan ini disimpan dan dimainkan, kalau berada di Kanekes. Yang paling penting untuk saya: saya minta masyarakat Baduy untuk memelihara dan main gamelan ini di Kanekes. Akan tetapi, kalau ragu-ragu mengenai persoalan tempat di mana gamelan disimpan, maka saya mengusul supaya gamelan itu disimpan di rumah jaro pamarentah (atau dekat rumah resmi itu di 
Jaro Saijah and Sapin asked me to talk to the people in Kadujangkung and explain what I had written in my letter. The next day, we met Anik (alias Arpani) in Kadujangkung. He had been responsible for daily matters, concerning the storage and playing of the gamelan since its return to Kanékés in December 2002. Anik read the letter (slowly, but he could read it!) and he was very happy about the suggested solution. He added that the bendé (small gong) had not yet been returned by Narja. However, he had seen the bendé at Narja's house in Cipangembar in Gunung Tunggal. That afternoon we came back to Kadujangkung for attending the pantun recitation during the ongoing circumcision and tooth filing rituals (see Section 4.4). Anik decided to immediately go to Cipangembar to collect the bendé, because Narja was home and intending to attend part of the circumcision rituals in Kadujangkung. A quarter to seven that evening they were back with the bendé; see Figure 42 . With the bendé returned, all gamelan instruments that I had given to jaro Samin in July 1979 were again united.

On 13 July 2016 the gamelan was carried from Kadujangkung to the house of the Kanékés village head in Kaduketug. Anik came to me and said that he had now finished his job: he was no longer responsible for this gamelan, and he seemed relieved. I thanked him for taking this task on his shoulders during several years. The musicians around jaro Saijah immediately started to play on the instruments and discovered some shortcomings: one of the kettles of the keromong instrument had a hole in it and the tuning of the kettles was not entirely correct. In addition, one of the caning had a broken bronze key. Moreover, there was no gambang xylophone and no second gambang kendang, the 'drum xylophone'.

After this fieldwork I left Kanékés again on 22 July 2016, with the promise that the returned gamelan would be completed with two gambang, one of them being a 'drum xylophone' (gambang kendang), and both tuned properly in the saléndro tone system. Moreover, one kettle of the keromong instrument would be replaced and also one key of a caning metallophone. My assistant Mumu would arrange this with the help of two musicians from the Bandung Conservatory (present-day ISBI: Institut Seni Budaya Indonesia). In the 1980s I already met with one of these musicians, Dody Satya Ekagustdiman (b. 1961). He is also a successful composer and I fully trusted his ability to deal with the Baduy musical instruments, as he had been in Kanékés several times. ${ }^{21}$ The

Kaduketug), karena gamelan itu sebenarnya berada pada yurisdiksi jaro pamarentah dan pimpinan Kanekes yang lain. Kalau disimpan di rumah resmi jaro pamarentah, maka lebih jelas bahwa gamelan in bukan dimiliki satu orang, satu keluarga, atau satu lembur Baduy, tetapi dimiliki keseluruhan masyarakat Kanekes yang diwakili oleh jaro pamarentah.'

21 See a short curriculum vitae of Dody, for instance, on <https://de.wikipedia.org/wiki/ Dody_Satya_Ekagustdiman $>$. [Last access 9 November 2017.] 


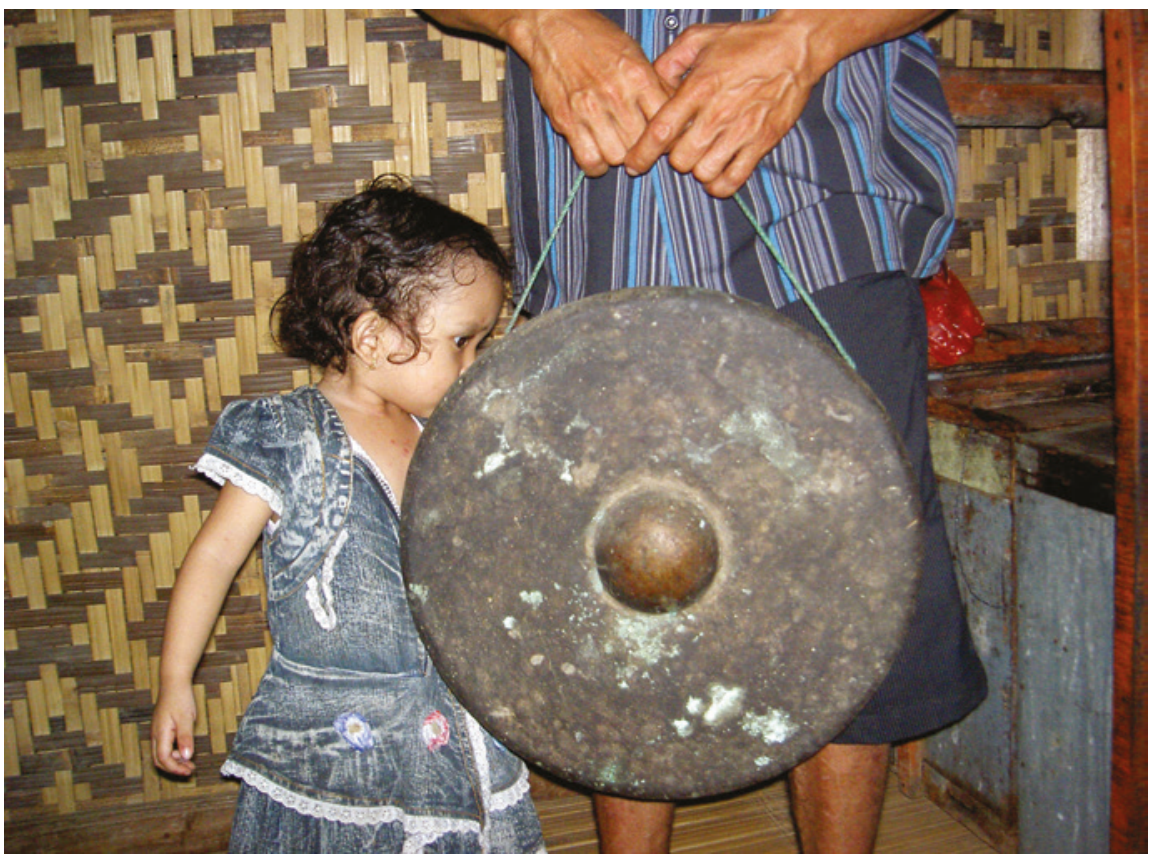

FIGURE 42 The bendé small gong, just returned to Kanékés from Cipangembar, Gunung Tunggal, and shown by Ayah Anik and his daughter at his house in Kadujangkung, 2 July 2016

other musician was Adhiyono, who had been Dody's pupil. On 24 July 2016 Mumu and I met them in Jelekong, Bandung, and spoke about this necessary work on the gamelan. As a last contribution to the safeguarding of this gamelan, I paid the costs of 10 million Rupiah (about $€$ 707, US\$ 780) for getting the job done.

Dody and Adhiyono worked for three days, still in the 'gamelan season' before the 'angklung season' started, and on 11 August 2016 the job was finished. Mumu arranged a 'memorandum'/agreement (perjanjian) and sent me a report, dated 11 August 2016, with photographs. This memorandum summarized the position of the gamelan as a communal property and that it had been tuned and expanded with two xylophones. It was signed by Mumu, Dody and Adhiyono and a Bandung witness. For the Baduy jaro pamaréntah Saijah signed with two witnesses: Ayah Anirah and Saijah's neighbour Arwan. Mumu reported that he saw and heard this keromong being played just before the start of the séba on 28 April 2017. However, whereas in 2016 and 2017 the gamelan had been played just before the start of the séba, that was not the case at the start of the séba on 20 April 2018. According to Ayah Anirah it was forbidden 
to play the gamelan at that time (E-mail messages from Mumu, 3 May 2017 and 15 April 2018).

\subsubsection{Commentary}

The origin of this gamelan is not clear. In contrast to what Talsim told in the interview in April 1976 (see above), it is almost certain that the instruments were made outside Kanékés, because that is the case with all other Baduy gamelan that I saw. Baduy gamelan (keromong) are bought outside Kanékés and not made by Baduy smiths. On 10 December 2013 the village head Daénah told me: It is impossible that the gamelan bought from Talsim in 1976 was sold because a Baduy family had debts. Such things do not happen. He added: this gamelan was first sold to Talsim by the puppeteer (dalang) Abah Sunarya, from Jelekong, Balé Éndah, Bandung. ${ }^{22}$ The gamelan was then used for playing at the wedding of the former secretary of Kanékés, Ukang Sukarna, and soon after this wedding it was sold to me. Talsim had bought the gamelan via Bernard Suryabrata, Daénah said (A2013: 31-32). Jaro Daénah's comments made sense to me. It would be possible to investigate the history of this gamelan more thoroughly, however, I will not do so here.

As already mentioned, Baduy gamelan are tuned in the saléndro tone system: five notes in each octave and the same interval between consecutive notes. This was confirmed by the analysis of the three Baduy gamelan that I recorded in 1976. It is unclear to me why the tuning of the gamelan I bought in April 1976 and returned in July 1979, was called pélog by the seller Talsim in 1976 and also by Aki Armad (alias Hamdan) in 2013. What did this exactly mean? In the 1970s I did not pay attention to the precise tuning of the gamelan and I never recorded its tuning. In August 2016 this old tuning was destroyed by the change to a saléndro tuning as described above. Hence I could no longer get an answer to the question whether the designation 'pélog' indicated another tone system, or only meant 'other than saléndro', or 'out of tune'.

Part of the confusion around this gamelan was that in 1979 the Baduy society was upset by the resettlement project that had started in 1978. In fact, Samin was in 1979 still the official secular village head of the Baduy area, that is, of Kanékés village. However, because he moved to the resettlement village Cipangembar in Gunung Tunggal with about 80 Baduy families and no longer

22 Abah Sunarya was leader of the Pusaka Giri Harja wayang golék group and father of the famous puppeteer Asép Sunandar Sunarya (1955-31 March 2014) from the Giri Harja 3 group in Jelekong, Balé Éndah, Bandung. See further Sarah Andrieu's book on wayang golék in West Java and in particular for this family of Giri Harja puppeteers (Andrieu 2014: 110-113). 
lived according to Baduy rules, the spiritual leaders did no longer recognize him as member of the Baduy society. ${ }^{23}$ I did not understand this situation very well in 1979, otherwise I might have transported the gamelan immediately to Kanékés village, which is the 'safe' Baduy region. The ambiguity of Samin's position as village head (jaro pamaréntah) may have caused part of the later troubles with this gamelan that I returned to the Baduy community.

In a conference held in New Delhi, India, in 2007 I discussed this Baduy case of the returned gamelan in a presentation about prior informed consent in ethnomusicology recordings (Van Zanten 2009). One of the participants of the conference asked whether the present author's behaviour had been paternalistic, when he decided to return this gamelan to the Baduy community. I agree that this is a sensitive and important issue and needs to be taken seriously. My answer at that time was that the Baduy community could have refused the offer, if they had felt that the gift had too many negative effects. On the whole the Baduy only accept gifts without any obligation on their part. A gift might be felt as an insult. They should have the possibility to refuse a gift, as the secular village head Daénah had expressed when commenting on the government's programmes for Baduy resettlements in 1999 (see Section 2.2; Persoon 1994: 333).

In my discussions with the Baduy and migrated Baduy about the place where the gamelan was kept after 1992, the issue of paternalism was always in the background. My comment was mostly that I had given the gamelan to the Baduy community on the sole condition that it would not be sold again and disappear from Kanékés. So, the Baduy themselves should decide who would be responsible for the daily use of the gamelan and where it would be kept in Kanékés. I should not be involved in this decision. However, there seemed to be a deadlock that I still do not entirely understand: the gamelan seemed not to be played very often in Kadujangkung. According to the players this was because they did not feel very competent. At the same time, there were no plans to move it to another hamlet where it would be played.

During my visit to Kanékés in May-June 2014 the former village head and member of the family then responsible for the daily use of the gamelan in Kadujangkung, jaro Asrab, suggested that it would be best if I wrote a letter about moving the gamelan to the official residence of the secular village head in Kaduketug 1. I hesitated because this was in fact against my principles, but at the end I decided to write such letter (July 2016) and things started to move

23 See also Bakels and Boevink (1988: 77-88; note that they use the name Sapin, instead of Samin) and Persoon (1994: 345-6, 361) for the important role played by Samin in this resettlement process. 
into the direction that I wanted, and apparently also the Baduy leaders (see above).

Postscript November 2019. So far the history of this gamelan had a happy end: the gamelan was in good order and could be used for playing since August 2016. However, that changed on 12 September 2019, when there was a big fire in the hamlet Kadu Gedé in the northern part of Kanékés, lying in between Kadujangkung and Karahkal. The same day this fire was reported in the Internet newspapers: the fire had started after noon and a few hours later it was under control. However, 37 houses and an unknown number of rice barns had been destroyed. ${ }^{24}$ The next day my assistant Mumu wrote by E mail and passed on the information that he had received from Sandy, child of the pantun performer Anirah: all the houses of the hamlet had been destroyed, including the houses of jaro duabelas Saidi and pantun performer Anirah, but there were no casualties and the gamelan of the hamlet had survived: goong, saron and keromong. This was confusing information. According to my field notes jaro duabelas Saidi and Anirah were living in Kaduketer 2 that I had visited in 2016. A few days later Mumu answered my questions and wrote that Saidi and Anirah had moved to this new hamlet Kadu Gedé, in fact to a newly 'added hamlet' (babakan) of Kadu Gedé that was called Pasir Ciri. This new hamlet Pasir Ciri had been burnt.

A few weeks later, on 6 November 2019, Mumu reported that he had attended the ritual marriage of the rice to the earth (ngarérémokeun) in Kanékés, taking place during the night and morning of 3-4 November. His short description of this ritual with angklung playing was very similar to what I wrote in Section 4.2 about the 1992 rice ritual. During his visit jaro pamaréntah Saijah told him that the gamelan that I had returned in 1979 had been moved to Pasir Ceri/Kadu Gedé after August 2016 and it was burnt in the 12 September 2019 fire. Mumu also sent me a photograph of a burnt gong, taken by someone in Kanékés.

Here ends the life history of this Baduy keromong. It leaves us with some questions. According to Mumu's reports it seems that after my last visit to Kanékés in 2016, there had been different opinions as to where the gamelan should be kept and played: at the residential house of the secular village head (Saijah) in Kaduketug 1, or at the residence of the jaro duabelas (Saidi) in Kadu Gedé/Pasir Ciri? Mumu rightly pointed out to jaro pamaréntah Saijah that this choice was no business for Mumu or the present author: this gamelan had

24 See, for instance https://news.detik.com/berita/d-4703947/37-rumah-di-kampung-baduyterbakar [last access 1o November 2019.] 
been Baduy property since 1979. Further investigation might shed some light on what happened in this last conflict about the gamelan.

\subsection{Dancing}

The Baduy use several words for their dancing with angklung and keromong music: ngalagé, baksa, and topéng. The Outer Baduy may dance with the angklung: ngalagé. ${ }^{25}$ According to most informants, Inner Baduy are not allowed to dance (Karamaén, A2003-2: 4; Garna 1988: 89). In contrast, some Baduy informants said that Inner Baduy men were allowed to dance only during the angklung playing for the engagement ceremony of the goddess of rice (Nyi Pohaci, Déwi Asri) to the earth (Partiwi/Paratiwi). Although my information on this issue of dancing was not consistent, I am inclined to conclude that dancing with the angklung is allowed for Outer Baduy men, but forbidden to Inner Baduy.

Atik Soepandi and Enoch Atmadibrata (1977: 70-72) describe the ngalagé dancing for the whole of Banten and indicate that it is everywhere connected to the harvesting or planting of rice, but it takes different forms. The first one is dancing with the angklung, which ends with the drum players running around in a group in a coiling way, 'like a snake': the tail following the head, wherever it goes. It is called oray-orayan. This is similar to what I described for the dancing with the Baduy angklung:

In the last and fast section of the musical piece, when the angklung players stood still, the dancers started running around the players. They went clockwise and counter-clockwise, turning regularly. Their hands were kept low, and their bodies were bent, as if they were searching for something. They gave me the impression they were imitating birds. The dancers were followed (chased?) by the drum players'.

VAN ZANTEN 1995: 536

Djoewisno (1988: 47-48) describes this Baduy 'dancing (tarian)/running around' as 'roaming about like people who are dizzy'. This is then followed by 'dancing' of two middle-aged men in opposite directions 'in the style of people who are possessed' (kesurupan) that turns into a mock fight (pertandingan adu kekuatan). Soepandi and Atmadibrata (1977: 70-71) give other forms of

25 Only one person, Sardi from Cikarého, Kompol, used 'réog' for singing and dancing with angklung (A2O14-1: 12). 
ngalagé in west Java, like the dancing in two rows to the angklung and dogdog lojor drums players, in which everyone in the audience may dance to the angklung music with drums.

Budi (2015: 229-230) mentions that during the planting of rice ceremony on dry rice fields (ngaseuk) in Kasepuhan Ciptagelar, 40 km southeast of Kanékés, the ngalagé dancing is done by only one man, accompanied by the angklung dogdog lojor. Budi describes the movements of the dancer as mincid: to 'walk' with small steps and staying on the same spot. ${ }^{26}$ There is no dancing during the similar rice ceremony for the wet rice fields (sawah) in Ciptagelar, although the angklung dogdog lojor is also used in this ceremony (Budi 2015: 246-247). At the harvest feast (sérén taun) in Kasepuhan Ciptagelar the angklung dogdog lojor is also played during the cutting of the rice (mipit) and people may dance to it; this is called ngalagé, but also ngigel (Budi 2015: 265; see also Budi, Soedarsono, Haryono and Narawati 2014).

Van Tricht (1929: 44, footnote 1) reported an interesting story from the geologist E. Ganz, who told him that he was not allowed to take photographs in Cibéo: '... during one of his excursions in the Kendeng mountains he arrived on his own in Cibéo where he started to take photographs. The Baduy guided him politely outside the hamlet while they kept dancing around him in a circle'. Maybe the word 'dancing' should here not be taken too literally, as these are concepts and words used by the outsider Ganz, however it remains an intriguing issue whether the tangtu men may dance or not.

One of the earliest reports on Baduy, including notes on language, music and dance, is from Spanoghe. In his notes taken during a visit to an Inner Baduy hamlet in 1823 he describes a dance with rattan sticks: "They love to dance with rattan sticks and, like other people in Banten, hit each other with these canes during the dancing'. I have heard about the existence of this dance in which two men try to hit each other with a cane or whip in Banten. In the 1940s this dance apparently occurred in several forms all over Indonesia. ${ }^{27}$ Baduy never mentioned to me that they perform this dance. However, Hasman and Reiss (2012: 36) note that during raraméan festivities of the Inner Baduy with angklung: 'There is a duel using whips in which men pair off and try to hit one another on the legs. This goes on until after midnight'.

26 Eringa (1984) gives the same description for mincig.

27 See, for instance, film fragments of these cane/whip dances in Kalimantan and Flores in the late 1940 s in the documentaries made by the Dutch Information Services (Rijksvoorlichtingsdienst) in: 'In de schaduw van de waringin - Volksvermaken; Leven en bedrijvigheid in Indonesië 1947-1949', 1om20s - 12m53s. A copy is kept at the Instituut voor Beeld en Geluid: <https://www.beeldengeluid.nl/>. 
Whereas in the different Sundanese gamelan the drums (kendang) are very pronounced, the Baduy keromong do not use drums and officially Baduy are not allowed to dance with gamelan. I assume that the reason for this is that drums are strongly associated with dancing and erotic feelings (see also Djatisunda 1995: 8). Henry Spiller elaborated on this in his book (2010) about the 'erotic triangle' between female vocalist/dancer, drum player and male dancer in Sundanese music. In the existing literature the female vocalist/dancer ronggéng was mostly described in negative terms. Raffles (1817:342) wrote that ' $[t]$ heir conduct is generally so incorrect, as to render the title of ronggéng and prostitute synonymous'. Also Koorders was very negative about the ronggéng. On 23 June 1864 he wrote about Rangkasbitung: 'Ronggéng, that plague for the people, are not tolerated here; the Javanese influence has only taken them to the northern part, to the Sérang region'. (Meinsma 1869: 319).

In December 2013 I noticed a change in keromong music: the introduction of a 'drum xylophone' (gambang kendang) in the ensemble just bought by the secular village head Daénah in Kaduketug. This 'drum xylophone' was added between 2003 and 2013 to the regular keromong ensemble that contains already a xylophone (gambang) playing the melodic parts; see Plate 1 in Van Zanten (2015: 119).

There is another form of dancing to keromong music. As mentioned in Chapter 4, during the circumcision ceremonies Inner and Outer Baduy men may dance the baksa dance with the accompaniment of the keromong ensemble. Further, officially Outer Baduy are only allowed to dance (ngalagé) with angklung. However, in current practice dancing also takes place during the playing of keromong for entertainment and it is done by both men and women, as we have observed in Chapter 4. This dancing is called topéng, and according to Eringa (1984) this is short for ronggéng topéng. During my 9 December 2013 keromong recording there was rhythmic clapping of hands and a man was moving his body to the played music, again a sign of the relation between clapping, drumming ('drum xylophone') and dancing.

In January 2014 Mumu, who had assisted me on two previous journeys to the Baduy, filmed Outer Baduy men and women dancing to gamelan music during the wedding of Daénah's son. Officially this dancing is not allowed by the spiritual leaders of the Baduy. The major occasion for dancing is during the playing of the angklung for entertainment and that includes drums (Van Zanten 2015: 119-120). Further, dancing is allowed during two short periods of about five minutes in the circumcision ceremonies: $b a k s a$. In other parts of West Java baksa indicates a male dance performed by an even number of participants.

Kurnia and Sihabudin also mention the baksa dance (2010: 211): on the third and last evening of the circumcision ceremony, the boys that will be 
circumcised the next morning were given coconut and brown [palm] sugar to eat. After eating this blessed food the boys were taken by their fathers to dance ('... sambil diangkat oleh bapaknya dibawa menari-nari ...'). The authors remark that this event is especially to entertain the circumcised boys and their families so that they feel happy.

See for more details on the dancing with angklung (ngalagé) my earlier article (Van Zanten 1995: 532-537). See also information and an interesting picture showing two Baduy men mock fighting (dancing?) with angklung accompaniment in Djoewisno (1988:44-48). However, we need more information to get a better picture of the position of dance in and around Kanékés.

\subsection{Gender Aspects and Gendék Ceremonial Pounding of Rice}

This section will briefly raise the issue of gender equality in the Baduy community and especially with respect to music and dance. What is the role of women according to Baduy ideological views and how is it implied in public life? Is this very different from the groups around them?

Gerard Termorshuizen summarized and evaluated 19th century Dutch reports on the Baduy. He concluded that these reports presented the image of the 'noble savage', and generally reflected the idea that unfortunately, the 'aggressive and murderous Islam' spoilt the pure nature of the native people (Termorshuizen 1993: 14, 18; see also Section 3.3). In later periods the Baduy were considered to be 'authentic' and representing the 'true' and 'pure' Sundanese culture of the past. Their way of living has been considered a 'moral mirror' and also showing 'primitive' and/or 'mysterious' aspects (Wessing and Barendregt 2003: 90-91).

Baduy consider themselves to be the 'elder brothers' of the rulers north of Kanékés, their 'younger brothers', who are supposed to protect them. The Baduy ascetics with spiritual powers advise the rulers with worldly power. Berthe $(1965: 222)$ adds that '.. the principal characteristic of the elder is femininity; that of the younger, in contrast, is masculinity'. See further the discussion on the séba ritual, in which the Baduy show their respect and advise their 'younger brothers' on important issues, in Sections 2.4 and 6.1.

Unfortunately little has been written on the specific position and the image that outsiders constructed of Baduy women. This section only mentions a few general gender issues raised in the existing literature and then moves on to the domain of music and dance. With respect to the image of Baduy women, several times I have heard non-Baduy Indonesians saying - with some admiration - that they are more autonomous than those of the groups surrounding Kanékés. 
These outsiders supported the image described by the Dutch resident of Banten, Bedding, when passing on his job to another resident (Memorie van overdracht Resident Banten, (24 maart 1925)). Gerard Persoon quoted from this 1925 report:

The position of women in the Baduy society ... is generally as high as with the Europeans, if not higher ... In this respect the Rawayan [Baduy] are right that they defend themselves as effectively as possible against the penetration of Islam. The Karang people [living east of Kanékés] do not have such defences and will before long be absorbed by the same religion as the one of the surrounding great masses.

PERSOON 1994: 316

The image on the relatively autonomous position of Baduy women is supported by some facts. On the organizational level Geise (1952: 26-28) mentions that the function of jaro dangka is hereditary along both the male and the female line, and he gives examples of this. Although the male line seems to be stronger, two examples clearly show the existence of female hereditary. ${ }^{28}$ In Section 2.1 was mentioned that the most important Baduy officials cannot stay in office when their wife dies. ${ }^{29}$ The official's wife is needed in rituals. This shows that in gender terms there is a reasonable balance in hereditary matters.

In her book on gender aspects in the Baduy community Permana (2001: 6676) reports that there are three basic concepts in Baduy life that support gender equality: Ambu (literally 'mother': female principle), Nyi Pohaci (goddess of rice) and balance (keseimbangan); see also Permana (1999). The word ambu (mother) is used for female human beings, but also for heavenly rulers, and the Baduy have female ancestors, as mentioned in Section 3.2. In the yearly engagement ritual of Nyi Pohaci Sangiang Asri, the goddess of rice is the central

28 The second example is about a Muslim man Ki Amidin who was head of a hamlet (Gunung Telaga) outside Kanékés. He married a Baduy woman of dangka descent, Ambu Arpi from Karahkal, Kanékés. Because of his wife's dangka descent, the Baduy elders appointed Ki Amidin as jaro dangka of Kaduketug, after a purification ritual. Hence he became Baduy. Their daughter Arpi married a Muslim man Arpan and they had a son Sarman. Sarman married a Muslim woman. After a purification ritual Sarman became jaro dangka of Kamancing. Ki Amidin and Sarman from Muslim communities could be 'drawn into' the Baduy community because of the dangka descent of their wives (Geise 1952: 27).

29 Geise (1952: 27) mentions that, in contrast to this rule, the earlier mentioned Ki Amidin remained jaro dangka of Kaduketug when his wife died and when he remarried. His son from this second marriage, Arja or Ki Yaisin, also became jaro dangka of Kaduketug. 
figure, not her (future) husband, the earth Partiwi; see Section 4.2. Permana (2001: 71) remarks about the 'balance' that: 'This balance holds for all fundamentals of living, for the relations between human and human, human and animal, human and other creatures, as well as human and environment'. According to Permana this all shows the important place of the female principle in Baduy society.

In many ways these concepts that support gender equality according to Permana ('female principle', Nyi Pohaci, and balance) hold for the whole of Sunda, as discussed in Van Zanten (1989: 42-51, 194, and 207). In later publications I emphasized that '... the Sundanese arts represent female aspects of human communication ...' (Van Zanten 1994: 86-87; 2008: 42) and stated that 'Emotional feelings should not be expressed too overtly in daily life. That is considered to be bad behaviour, especially for men. However, a musical setting gives the opportunity to communicate these feelings' (Van Zanten 2008: 49).

As a last remark on these general gender issues I would like to say that, like for Baduy religion, the rules dealing with gender seem to be applied in a practical, rather than in an ideological way (compare remarks about the syahadat in Section 2.3). Boys may weave (see Figure 21) and girls occasionally play keromong instruments. This topic of gender deserves a more elaborate treatment. However, I will now move on to musicians and gender and music that is exclusively performed by women.

\subsubsection{Musicians and Gender}

Most musical instruments are played by boys and men, and Outer Baduy men also sing in pantun stories and with the angklung ensemble. Women play far less instruments; only the karinding Jew's harp is commonly used for courting and especially by Inner Baduy women. However, as regards music playing by women, Baduy rules seem not to be very prohibitive. In my field notes from 11-12 June 1976 I wrote that gamelan instruments are in principle only played by boys and young men, but on 12 June I noted that girls played the caning metallophone and the keromong instrument consisting of ten bronze kettles resting on a horizontal frame in the recorded Gajéboh gamelan (A19761977: 10, 18-19). It must be added that in 2013 and 2016 I did not see women playing one of the keromong instruments at the attended circumcision and wedding rituals. At these occasions women sang and danced with the keromong ensemble and nowadays young men join in the dancing (see Section 5.3 and Figure 16$)$.

Like men, women also sing with the accompaniment of a few instruments, as will be discussed in Section 7.3 for Raidah. Female vocalist Raida(h) was 
also mentioned in my 1995 article and there I also pointed out that the Baduy seem to have followed the mainstream Sundanese music tradition: in current practice the vocalist in gamelan music is more likely to be a woman than a man (Van Zanten 1995: 531-532, 542-543). In Section 1.2 I also mentioned that I have heard women singing softly for themselves, when doing a job. This includes lullabies and as yet we lack sound information on this.

Geise (1952: 36-37) mentions the story of the rice planting ritual as told by Ambu Sairan. She told him about the angklung playing and singing during the engagement (ngarérémokeun) part of the wedding of the rice to the earth that 'women cannot do this, it is not customary' (bikang teu bisa, teu kaprah). This rule still holds. However, women have other important tasks when it concerns the rice: they pound, cook and serve the rice. Moreover, circumcisions, weddings, and other important occasions without direct relation to the rice are announced by ceremonial pounding of the rice by married women: gen $(d) e ́ k$. This rhythmic stamping also happens in other parts of West Java and is generally called gondang or tutunggulan (Eringa 1984; Figure 43).

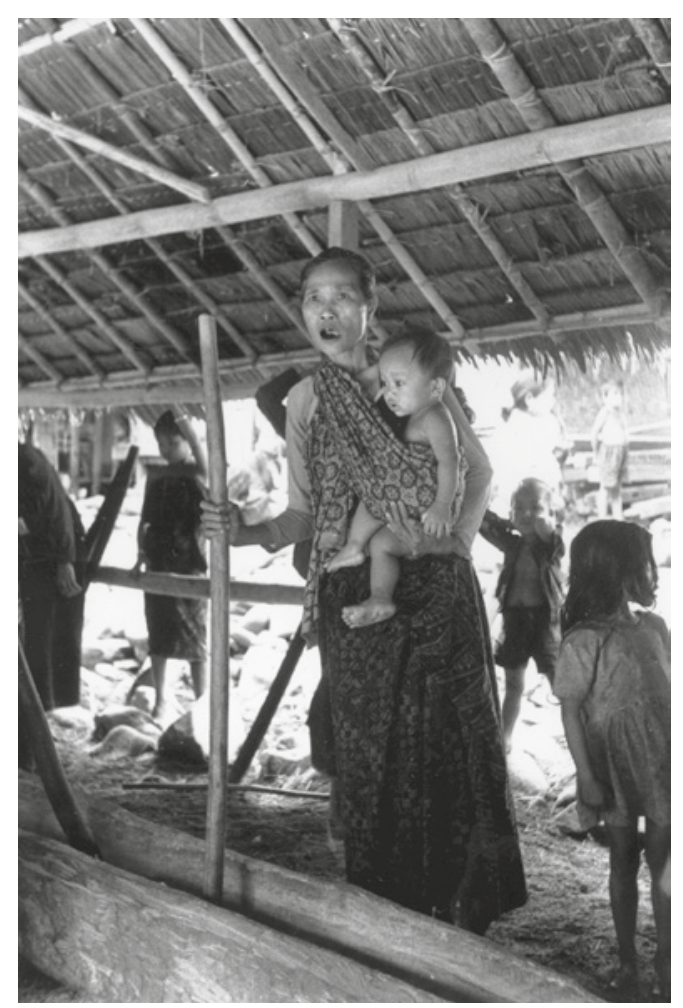

FIGURE 43

Woman and children at the gendék ceremonial pounding of rice. Gajéboh, 13 June 1976 


\subsubsection{Gendék}

Every hamlet has a 6-8m long wooden trough (lesung) in an open, roofed space (saung lesung) for pounding rice with a pestle (halu). For daily use women go there to pound rice for their family. Often there are several women pounding rice and now and then the pounding women may produce repeated rhythmic patterns that presumably also makes the work lighter: work songs, or rather work rhythms. On special occasions, playing these rhythmic patterns is done with an empty trough and used to announce an important event to the people in the neighbourhood. This is mostly done for life-cycle events, such as circumcisions and weddings, and it happens one or a few days before the event. This pounding by a group of 8-20 married women is called gendék and the Outer Baduy classify this rhythmic pounding as a type of music.

Film $<\mathrm{AV} 1 \mathrm{O}>$ is a sound film of gendék made in Babakan Kompol on 26 July 1976. The used empty trough is small and there are only eight women pounding on this occasion. When the pestle is used in an empty trough the sound will carry further than when there is rice in it. However, as already mentioned these rhythmic patterns are also produced when pounding with rice in the trough. On 18 July 2016 I recorded such pounding again and was told that this was gendék (A20162: 3), as the rice was pounded for the ceremonial meal to be held during the planned visit of Indonesia's president Joko Widodo (Jokowi). Listen to $<\mathrm{AV} 11>$.

We may ask whether these gendék rhythmic patterns are similar to the patterns produced by the drums in the angklung ensemble, or on the recently introduced gambang kendang of the keromong ensemble. Unfortunately, the scope of this book does not allow me to look into the details of the produced rhythmic patterns, with or without rice in the trough.

Budi (2015: 130) reports that in the Kasepuhan Ciptagelar the women perform the ceremonial pounding (tutunggulan) while singing and dancing (berjogét). This tutunggulan mostly happens at the time the rice is harvested and put in the rice sheds (sérén taun).

In this chapter I looked more closely at some musical characteristics of Baduy music. In Section 5.1 I discussed some general concepts like the tone system, musical modes and styles of playing. I concluded that for the moment we may conclude that Baduy use the saléndro tone system in their music (equidistant pentatonic). The tolerance for the tuning is great: precise intervals seem to be of less importance. I also concluded that for Baduy musicians, pélog probably in the first place means a tone system that deviates from the preferred saléndro system. In this chapter I also discussed some musical features of the angklung and keromong ensembles. Section 5.4 tells the story of the keromong set of instruments that I bought in 1976 and returned to the Baduy community in 1979. Further I discussed dancing and some gender issues. The next chapter will discuss pantun storytelling. 